\title{
Dependency of Microalgal Production on Biomass and the Relationship to Yield and Bioreactor Scale-up for Biofuels: a Statistical Analysis of 60+ Years of Algal Bioreactor Data
}

\author{
Tim Granata ${ }^{1}$ (D) \\ Published online: 19 August 2016 \\ (C) The Author(s) 2016. This article is published with open access at Springerlink.com
}

\begin{abstract}
Since the 1950s, research has been undertaken to promote algal oil as a sustainable alternative to fossil fuels. This paper statistically analyzed 317 studies of algal bioreactors to determine the interdependence of biological and physical factors affecting oil yield. Algal growth rates in bioreactors often (71\%) exceeded maximal growth rates cited in the literature, and biomass was generally higher than maximum values cited for laboratory cultures. Growth rate decreased with increasing biomass, and biomass, not growth, dominated production rate, which was higher in closed than in open bioreactors. Except for Chlorella cultured in horizontal tubular reactors, there were no statistical differences in algal production when grown in different types of reactors. Production decreased with increasing bioreactor volume, but increased with surface to volume ratio of the bioreactor. In contrast, estimated oil yields increased with bioreactor volume. Four groups of bioreactors were identified based on their oil yields and biomass production: (1) higher yields with lower production were limited to open systems with volumes $\geq 10^{4} \mathrm{~L}$; (2) higher yields with higher production were almost exclusively closed bioreactors from $10^{2}$ to $10^{3} \mathrm{~L}$; (3) lower yields with higher production were closed systems from 3 to $99 \mathrm{~L}$; and (4) lower yields with lower production were a mix of open and closed systems with diverse volumes. Based on these groups, it is suggested that intermediate volume bioreactors with higher surface to volume ratios could give higher yields and production rates and would avoid the environmental and
\end{abstract}

Tim Granata

timothy.granata@hslu.ch

1 Competence Center for Aerospace, Biomedical Science, and Technology, University of Lucerne Applied Sciences and Arts, (Hochschule Luzern) Seestrasse 41, 6052 Hergiswil, Switzerland scale-up problems inherent in large bioreactors currently being used commercially to culture microalgae.

Keywords Algal bioreactors · Productivity · Biomass · Scale-up

\section{Introduction}

Research on algal production rates for biofuels and commercial products has lead to a plethora of work on open bioreactors, such as ponds [1-34] and raceway flumes [4, 34-66], and closed bioreactors, such as vertical [67-91], horizontal [34, 40, 92-142] and helical tubes [97, 143-154], flat plates [66, 155-184], and other unique designs [133, 185-189]. This research dates back to the early 1950s and was chronicled in a historical perspective by Borowitzka [190].

Most species that have been studied produce only 30-50\% of their biomass as lipids [191, 192]. Given this limitation in cell lipid storage, the focus on increased biofuel yields has been on operating bioreactors to optimize the culture conditions and increase production. To maintain high yields of biofuel from microalgae-based processes, it is essential to devise culture systems that deliver high lipid content and high primary productivity. The former can be achieved by selecting target species to optimize neutral lipid production and storage. The later can be achieved by increasing biomass, cell growth rate, and volume of the culture system. High biomass, growth rate, and to some extent, lipid content are enhanced by optimal culture conditions through regulation of temperature, nutrients, and irradiance. However, to achieve these culture conditions, the size of the bioreactor can vary from the laboratory flasks of $10^{-1} \mathrm{~L}$ to large raceway ponds, on the order of $10^{6} \mathrm{~L}$.

Many excellent reviews have compared the various designs and provided photographs and illustrations of these bioreactor 
systems [66, 96, 190, 193-201]. However, few papers have examined statistical relationships from these bioreactor studies, with the exception of Williams and Laurens [199], who determined that closed bioreactors were more productive than open systems. This paper has compiled over 60 years (19532015) of data from review articles and their original references, special reports, and recent articles on algal culture systems and has statically analyzed optimum algal production rates (i.e., algal primary production or productivity) based on the algal class, cell volume, growth rates, biomass concentration, the bioreactor type, and the volume of the bioreactor. Maximum growth rates in laboratory cultures were compared to growth rates in larger $(>1 \mathrm{~L})$ bioreactors. Bioreactor biomass was compared with data from both the laboratory and phytoplankton ecology. Finally, the most effective culture systems for increasing production rate were examined, as well as how predicted oil yields vary with scale-up of the culture system. This paper does not evaluate the types of lipids produced by algae, which is very important to biofuel commercialization - see "A matter of details" [202], but focuses instead on the efficacy of bioreactors as culture systems.

\section{Methods}

Data were collected from 189 articles, comprising 317 experiments on the cultivation of microalgae in open and closed bioreactors. From these articles, information was collected on algal species, specific growth rate $(\mu)$, biomass of the culture $(B)$, production rate $(P)$, and bioreactor type, volume $(V)$ and illuminated surface area (SA). All articles reported production rates as either mass per volume per time $\left(\mathrm{g} \mathrm{L}^{-1}\right.$ day $^{-1}$ as dry weight) or mass per surface area per time $\left(\mathrm{g} \mathrm{m}^{-2}\right.$ day $\left.^{-1}\right)$. In this paper, the bioreactor volumes are in liters; therefore, units of $\mathrm{g} \mathrm{m}^{-2}$ day $^{-1}$ were converted to $\mathrm{g} \mathrm{L}^{-1}$ day $^{-1}$ by multiplying the appropriate surface area and dividing by the culture volume in liters. For studies that did not report growth rates (73\%), growth was determined from the plot of biomass over time in the article. However, if no plots or data were presented, the relationship $\mu=P B^{-1}$ was assumed valid.

Bioreactors were grouped into seven types: two open and five closed bioreactor systems. The two open systems were raceway ponds (RW, $n=84)$ and ponds $(n=53)$, and the five closed systems were vertical tubular reactors (VTR, $n=30$ ), helical reactors $(n=17)$, horizontal tubular reactors (HTR, $n=58$ ), flat plate reactors (FP, $n=56$ ), and unique reactors (UBR, $n=10)$, which included cascades $(n=5)$, cones $(n=3)$, and dome/parabolic $(n=2)$. For bioreactors, both volume and surface areas were reported or calculated. Most studies (91\%) either reported the illuminated surface area of bioreactors or provided dimensions and orientation of bioreactors such that it was possible to calculate the surface area. For some studies of ponds and raceway systems where only the surface area was given, the volume was calculated based on depth. If no depth was given, a mean depth of $0.1 \mathrm{~m}$ was assumed, based a nominal depth of the majority of these systems using data from Benemann [203] and Oswald [204]. For deeper ponds, of say $0.2 \mathrm{~m}$, this would lead to twofold over-estimation of volume; however, this is still a small deviation in volume given the 2 to $10^{6} \mathrm{~L}$ range of bioreactors studied.

While all articles reported species and/or genus, few gave the cell size or cell volume. Most, however, reported the origin of parent cultures, in which case cell size was found by searching the culture collection's webpage for the target species' dimensions. For articles where this was not possible, cell size was taken from Round [205] and for diatoms from Cupp [206]. Finally, cell volume was calculated based on cell morphology as a sphere or cylinder, with chains and colony size based on these two shapes.

Most studies cited the maximum biomass or provided graphs of biomass dry weight in grams per liter $\left(\mathrm{g} \mathrm{L}^{-1}\right)$. Only $19 \%$ reported cell number per culture volume (i.e., cell concentration). In this case, cell concentration was multiplied by the biomass per cell using Strathmann's empirical relationship to convert to biomass [207]. Strathmann's equation specifies pg dry weight carbon (C) per cell as a function of cell volume, and was converted to $g$ dry weight biomass assuming that $52 \%$ of the biomass was organic matter on a dry weight basis. Although the Strathmann regression applies to marine phytoplankton, the same trend occurs for freshwater species [208].

Results for bioreactor systems were compared with regressions of maximal growth rates, biomass, and production taken from the literature, which represent optimal conditions in laboratory cultures. Maximum growth rates were plotted against cell volume for diatoms [209], coccolithophores [210], green algae and cyanobacteria [211], and mixed species [212]. Biomass from bioreactors was compared to maximum cell concentrations from laboratory cultures [213] after converting concentration to biomass using Strathmann's equation. Biomass was also compared to phytoplankton in temperate [214] and tropical [215] oceans after converting biomass per cell to $\mathrm{g} \mathrm{L}^{-1}$ dry weight.

Regressions for biomass per cell $\left(B_{\mathrm{c}}\right)$, normalized biomass $\left(B^{\prime}\right)$, cell concentration $(C)$, and maximum growth rate $\left(\mu_{\max }\right)$ all followed a power law relationship, where

$Y=a V_{c}^{b}$

Transforming to a $\log$ relationship, the equation for a line is as follows:

$\log Y=\log a+b \log V_{\mathrm{c}}$, 
where $Y$ is the parameter of interest, $\log a$ is the intercept, $b$ the slope, and $V_{\mathrm{c}}$ is the cell volume in $\mu \mathrm{m}^{3}$. The units and regression variables $a, b$, and $Y$ are given in Table 1 .

Data from bioreactors were plotted for Eq. 1b, and confidence intervals were determined. To compare with regression data from bioreactors, confidence intervals for regressions in Table 1 were plotted for the original data points or were estimated from reported sample size and standard errors.

All statistical tests were done in Microsoft Excel using XLSTAT 2013 (V6.04) and StatPlus 2009 (V5.8) software. Turkey's and Bartletts' tests were used to compare variances between groups while a chi-squared test was used to determine normality of group distributions. Given equal variance and normality, differences between linear regressions were tested using analysis of covariance (ANCOVA). To compare the effect of different factors on cultures, analysis of variance was performed for equal variance distributions, otherwise the non-parametric Krustal-Wallis test was employed or a Student $t$ test if only two means were compared.

\section{Results}

\section{Microalgae}

For the 317 bioreactor cultures referenced in this paper, a total of only 35 genera were used. However, some algae have been studied more than others. Green algae have been used in almost half of the studies (45.6\%) with $19 \%$ accounted for by
Chlorella spp. (Table 2). The second most studied class was cyanobacteria at $27 \%$, which was mostly Spirulina spp. (24\%). The unequal number of genera and species, some of which had small sample sizes, lead to unequal cell volume distributions for growth, biomass, and production regressions, as well as non-normality and unequal variances. Consequently, genera were grouped into classes to increase the sample size for statistical power.

\section{Growth Rates}

Maximal growth rates of microalgae have been found to be inversely proportional to cell volume (Table 1). Figure 1 shows that the highest growth rates in laboratory studies were for diatoms of all sizes followed by coccolithophores $>400 \mu^{3}$. The lowest growth rates were for cyanobacteria and green algae, which were similar for both unicellular and colonies of all sizes.

Marañón et al. [212] found growth rates of mixed cultures (i.e., not class-dependent) were between diatom and coccolithophore maxima and only varied inversely with cell volume for the larger $\left(\geq 100 \mu^{3}\right)$ cell volumes. Smaller cells $\left(<100 \mu^{3}\right)$ displayed the reverse trend, although the magnitude of growth rates of these smaller cells varied between maxima for coccolithophores and green/cyanobacteria (Fig. 1).

For the different species grown in bioreactors, growth rates ranged from 0.01 to 4.8 day $^{-1}$. Although growth rates from bioreactors also had an inverse relationship to cell volume for
Table 1 Coefficients for regression of cell biomass, cell concentration, and maximal growth rates, all based on Eq. $1 \mathrm{~b}$

\begin{tabular}{|c|c|c|c|c|c|}
\hline Parameter $(\log Y)$ & Units & $\log a$ & $b$ & $r^{2}$ & Reference \\
\hline \multicolumn{6}{|l|}{$\log$ Biomass } \\
\hline$B_{\mathrm{c}}$, Biomass cell $^{-1 \mathrm{a}}$ & pg C DW cell ${ }^{-1}$ & -0.314 & 0.712 & 0.90 & Strathmann [207] \\
\hline$B^{\prime}$, Biomass & $\mathrm{mgC} \mathrm{L}^{-1} \mathrm{mg}^{-1}$ cell $^{-1}$ & -0.965 & -0.158 & $0.96^{\mathrm{b}}$ & Rodríguez and Mullin [214] \\
\hline \multicolumn{6}{|c|}{$\log C$, cell concentration } \\
\hline Laboratory $^{\mathrm{b}}$ & cells $\mathrm{mL}^{-1}$ & 8.79 & -0.790 & 0.94 & Agusti and Kalff [213] \\
\hline Tropical ocean & cells $\mathrm{mL}^{-1}$ & 3.61 & -1.29 & 0.98 & Huete-Ortega et al. [215] \\
\hline \multicolumn{6}{|c|}{$\log \mu_{\max }$, Max. growth } \\
\hline Green algae, total & day $^{-1}$ & -0.164 & -0.073 & 0.11 & Adapted from Neilsen ${ }^{\mathrm{c}}[211]$ \\
\hline Cyanobacteria, total & day $^{-1}$ & -0.184 & -0.067 & 0.11 & Adapted from Neilsen ${ }^{\mathrm{c}}[211]$ \\
\hline Diatoms & day $^{-1}$ & 0.580 & -0.110 & 0.70 & Banse [209] \\
\hline Coccolithophores & day $^{-1}$ & 0.544 & -0.32 & 0.86 & Buitenhuis [210] \\
\hline Mixed, $>100 \mu \mathrm{m}^{3}$ & day $^{-1}$ & 0.220 & -0.150 & 0.86 & Marañón et al. ${ }^{\mathrm{d}}[212]$ \\
\hline Mixed, $<100 \mu \mathrm{m}^{3}$ & day $^{-1}$ & -0.430 & 0.190 & 0.94 & Marañón et al. ${ }^{\mathrm{e}}$ [212] \\
\hline
\end{tabular}

${ }^{a}$ Independent of light or temperature regimes

${ }^{\mathrm{b}}$ Assumed light saturated cultures at $222 \mu \mathrm{E} \mathrm{m}^{-2} \mathrm{~s}^{-1}$

${ }^{\mathrm{c}}$ New regression on volume using original data based on diameter

${ }^{\mathrm{d}}$ Original regressions for $>40 \mu \mathrm{m}^{3}$

${ }^{\mathrm{e}}$ Original regressions for $<300 \mu \mathrm{m}^{3}$ 
Table 2 The percentage of dominant classes, genera, and cell types represented in this paper. Of the 35 genera in the 317 studies, genera in fewer than two studies were not listed here; hence, the total is $92.6 \%$ and not $100 \%$

\begin{tabular}{|c|c|c|}
\hline Class/genus & Percentage $(\%)$ & Cell type \\
\hline Cyanobacteria & 27 & \\
\hline Spirulina & 24 & Colonial \\
\hline Nodularia & 1 & Colonial \\
\hline Synechocystis & 1 & Unicellular \\
\hline Diatoms & 18.5 & \\
\hline Phaeodactylum & 7.6 & Unicellular \\
\hline Chaetoceros & 3.8 & Chains \\
\hline Cyclotella & 1 & Unicellular \\
\hline Fistulifera & 1 & Unicellular \\
\hline Green & 45.6 & \\
\hline Chlorella & 19 & Unicellular \\
\hline Nannochloropsis & 9.7 & Unicellular \\
\hline Tetraselmis & 5.5 & Unicellular \\
\hline Scenedesmus & 4.8 & Chains \\
\hline Haematococcus & 2.8 & Unicellular \\
\hline Dunaliella & 2.4 & Unicellular \\
\hline Micractinium & 1.7 & Colonial \\
\hline Chlorococcum & 1.4 & Unicellular \\
\hline Prymnesiophceae & 6.2 & \\
\hline Pleurochrysis & 3.1 & Unicellular \\
\hline Isochrysis & 2.1 & Unicellular \\
\hline Other & 2.1 & \\
\hline Porphyridium & 1.7 & Colonial \\
\hline Total percent of classes & 99.4 & \\
\hline Total percent of genera & 92.6 & \\
\hline
\end{tabular}

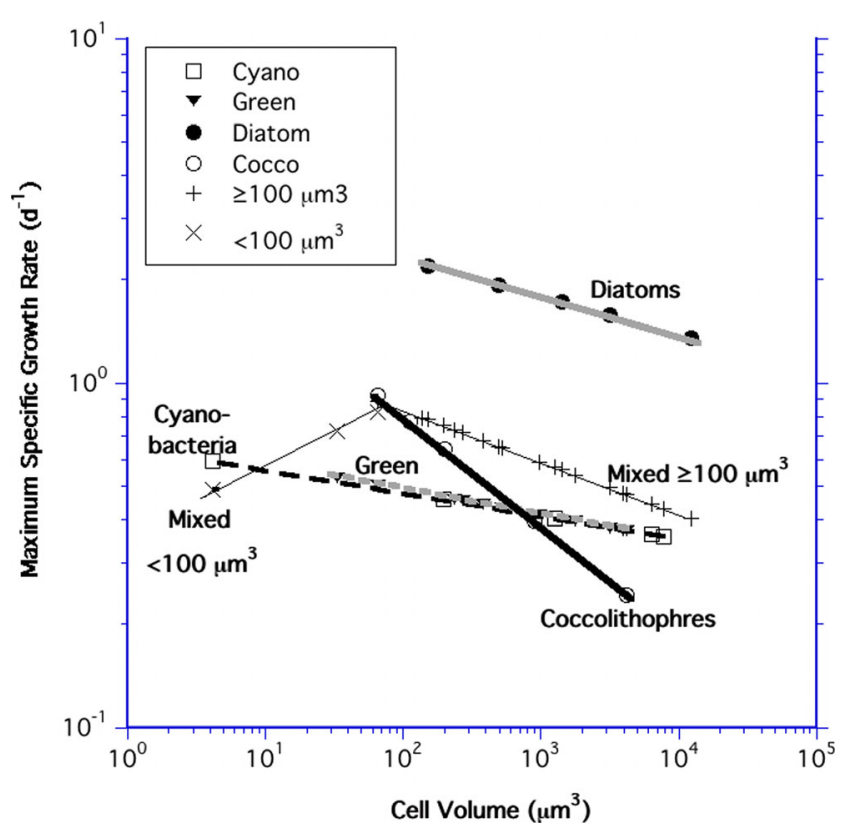

Fig. 1 Maximum growth rates as a function of cell volume based on Table 1 cyanobacteria, coccolithophores, diatoms, and green algae (Fig. 2), their low correlation coefficients indicated that cell volume did not explain the variation in growth (Table 3 ).

Confidence intervals for maximum and bioreactor growth rates of diatoms did not overlap (Fig. 2), indicating that growth in bioreactors was statistically lower than the maximum calculated by Banse [209]. The fact that confidence intervals for other algal classes did overlap, however, does not mean that maximum growth rates and those in bioreactors were not statistically different.

Even though growth rates were normally distributed for all the classes, the variance for coccolithophores was significantly lower than others $\left(X^{2}(3,227)=32.9\right.$; $p<0.0001)$. Because of the unequal variance and the lack of linearity, growth curves could not be directly compared for the classes. However, cell volumes binned to similar sample sizes showed growth rates were not significantly different for algal classes (Table 4). Additionally, growth rates were not statistically different for binned cell volumes (Table 4).

Comparing means of growth rates in bioreactors was not as meaningful as assessing the highest growth rates achieved in the bioreactors. Indeed, it does not make sense to compare average growth rates in large bioreactor.

For small laboratory cultures, maximum growth rates for cell volumes $<500 \mathrm{\mu m}^{3}$ were ranked as follows: diatoms $>$ coccolithophores $>$ cyanobacteria $=$ green algae. In contrast, the highest growth rates in the bioreactors were ranked as follows: cyanobacteria $=$ green algae $=$ diatoms $>$ coccolithophores .

Overall, $71 \%$ of the growth rates for the bioreactor studies were higher than maximum growth rates reported in the literature. Bioreactor growth rates exceeded maximal rates for 51 of 72 cyanobacteria, 14 of 18 coccolithophores, and 82 of 118 for green algae studies. Only once did the diatom growth rate in a bioreactor exceed the maximum rate, and this was in a bioreactor system under high light $\left(600-900 \mu \mathrm{Em}^{-2} \mathrm{~s}^{-1}\right)$ and low mixing for a short duration [113].

\section{Biomass}

The maximum, theoretical biomass (i.e., concentration) of an algal culture is given by the maximum number of cells packed per liter of culture and is based on the cell volume, and thus cell mass (Table 5). Several studies have shown that phytoplankton cell concentrations and standardized mass vary inversely with cell volume (and size), as seen by the negative slopes in Table 1. This is intuitive since a larger number of smaller cells can be packed into a liter compared to larger cells. However, Strathmann [207] showed that cell mass increases with cell volume (and size). Therefore, the maximum number of small cells in a liter of culture would have about the same biomass as fewer large cells in the same volume, and the maximum biomass should be constant for all cell sizes. Indeed, when converted to 
Fig. 2 Growth rates from bioreactor cultures (solid symbols, dashed regression lines) and maximum growth rates (open symbols, gray regression lines) versus cell volume. Confidence intervals are plotted at the $95 \%$ level for maximum growth rates (shaded in gray) and bioreactor systems (dotted lines). Regression constants for cultured systems are presented in Table 3

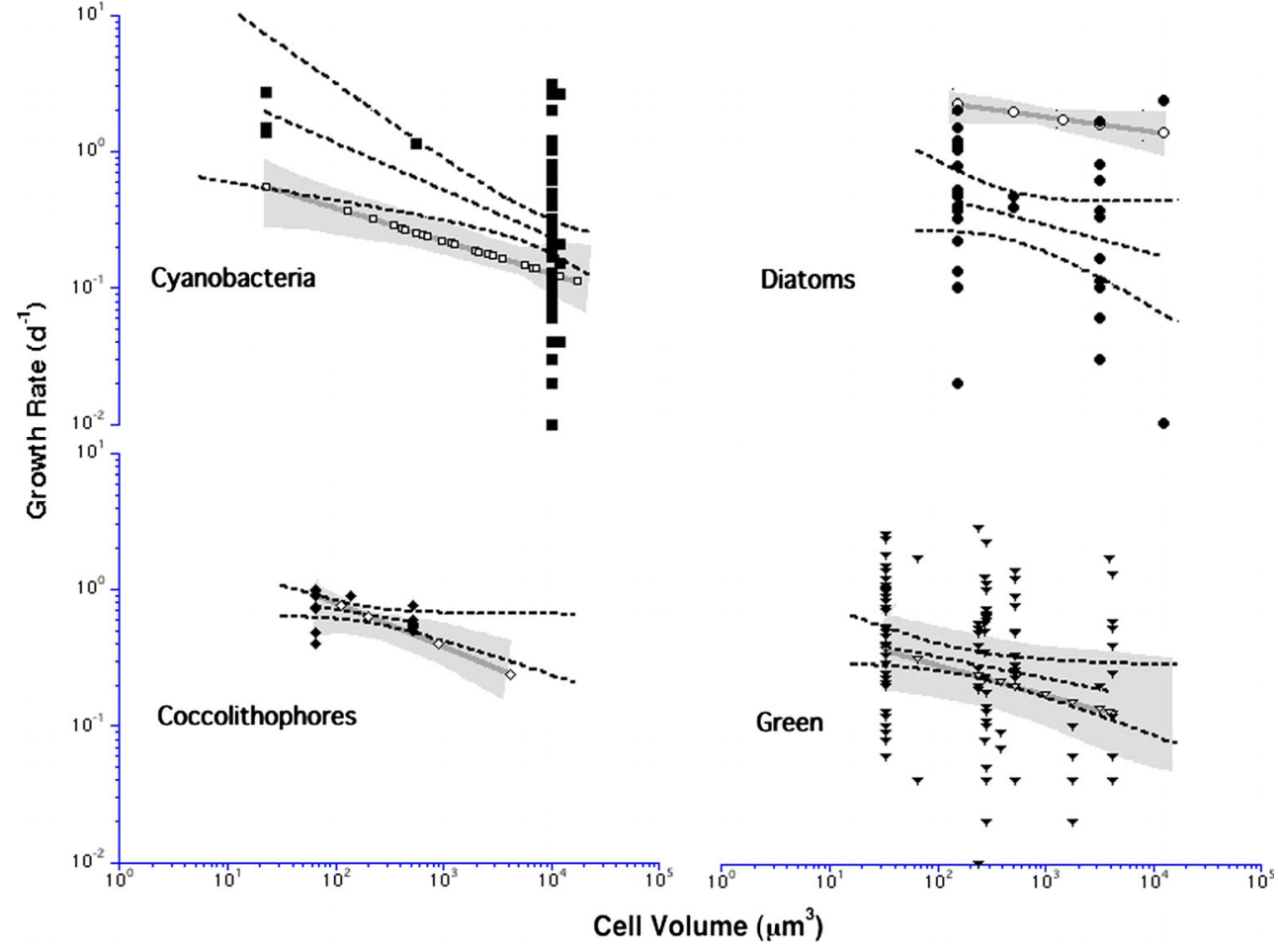

biomass in $\mathrm{g} \mathrm{L}^{-1}$ using Strathmann's equation, this inverse relationship of cell concentration on cell volume is much weaker (Table 4) since the mass per cell increases with cell volume making the slopes of biomass per cell volume less negative (Fig. 3).

The regression of bioreactor biomass over cell volume had a low correlation coefficient, and the slope was not statistically significant (Tables 5 and 6). Results of the ANCOVA for biomass comparisons showed a slight statistical significance $(P>0.033)$, which was attributed to growth rate $(|t|>0.015)$ but not to class or binned cell volume (Table 7).

Despite the large degree of scatter in bioreactor biomass, values were less than the packed cell biomass, but much greater than ocean populations, and overlapped the maximum biomass for laboratory data. Still, bioreactor biomass exceeded the maximum laboratory biomass in $86 \%$ of the samples. The maximum biomass and the biomass in the bioreactors were orders of magnitude greater than distributions in the natural environment, most likely because in aquatic environment, loss rates are higher (e.g., herbivory and bacterial/viral infects), and optimum growth conditions are seasonal.

\section{Production Rates}

The linear dependence of production rate on biomass and growth rate was compared, as was algal class and binned cell volume. Productivity was not statistically significant for binned cell volume or for algal class but did vary with both biomass and growth rate (Table 8 ). The fact that biomass is related to growth rate means that production could be directly affected by growth rate and indirectly affected by the influence of growth on the maximum biomass. However, it could also indicate that production is directly affected by biomass and that biomass affects growth, say by shading cells and reducing optimum growth conditions.

The maximum production rate in full sunlight has been estimated at $173 \mathrm{~g} \mathrm{C} \mathrm{m}^{-2}$ day $^{-1}$ for cultures grown on nitrate as a nitrogen source and about $200 \mathrm{~g} \mathrm{C} \mathrm{m}^{-2}$ day $^{-1}$ for ammonium [216, 217]. The later gives a biomass production of approximately $400 \mathrm{~g} \mathrm{~m}^{-2} \mathrm{day}^{-1}$ or $4 \mathrm{~g} \mathrm{~L}^{-1} \mathrm{day}^{-1}$ for a bioreactor with a $10: 1$ surface to volume ratio $\left(400 \mathrm{~g} \mathrm{~m}^{-2}\right.$ day $\left.^{-1} \times 10 \mathrm{~m}^{2} \mathrm{~m}^{-3} / 1000 \mathrm{~L} \mathrm{~m}^{-3}\right)$, which is within the range calculated by Williams and Lauren [199].
Table 3 Regressions of bioreactor growth rates as a function of cell volume, $V_{\mathrm{c}}$, for the four major algal classes

\begin{tabular}{lcccccccc}
\hline & $F$ & $P$ & SS & \multicolumn{1}{l}{$n$} & \multicolumn{1}{l}{$\log a$} & $a$ & \multicolumn{1}{c}{$b$} & $r^{2}$ \\
\hline Cyanobacteria & 10.6 & 0.002 & 2.47 & 72 & 0.466 & 2.922 & -0.282 & 0.131 \\
Coccolithophores & 4.21 & 0.058 & 0.05 & 17 & 0.127 & 1.340 & -0.124 & 0.167 \\
Diatoms & 0.44 & 0.512 & 0.10 & 35 & -0.214 & 0.611 & -0.084 & 0.013 \\
Green algae & 6.93 & $<0.01$ & 1.89 & 116 & -0.040 & 0.912 & -0.195 & 0.049 \\
\hline
\end{tabular}


Table 4 ANCOVA results for growth rates by class and binned cell volumes

\begin{tabular}{lrcccc}
\hline Source & df & \multicolumn{1}{l}{ SS } & MS & $F$ & $P$ \\
\hline Class & 4 & 8.176 & 2.044 & 1.363 & 0.247 \\
Error & 237 & 355.36 & 1.499 & & \\
Total & 241 & 363.54 & & & \\
\hline
\end{tabular}

Production in bioreactors varied from $2 \times 10^{-3}$ to $12 \mathrm{~g} \mathrm{~L}^{-1}$ day $^{-1}$ with biomass changes from $3 \times 10^{-3}$ to $67.3 \mathrm{~g} \mathrm{~L}^{-1}$ and growth rates from $10^{-2}$ to $4.8 \mathrm{day}^{-1}$ (Fig. 4a). Mean values were $0.74 \mathrm{~g} \mathrm{~L}^{-1} \mathrm{day}^{-1}, 3.4 \mathrm{~g} \mathrm{~L}^{-1}$, and 0.61 day $^{-1}$ for production, biomass, and growth, respectively. Although it may seem odd to plot biomass and growth as a function of production (and not vice versa), this clearly shows that biomass was more correlated than growth rate to production as seen by the slope of the regression lines in Fig. 4a.

Additionally, for production rates $\geq 1 \mathrm{~g} \mathrm{~L}^{-1}$ day $^{-1}$, the mean growth rate was 0.79 day $^{-1}$, which was only $18 \%$ greater than the overall mean, while the mean biomass was 8.7 , nearly triple that of the overall mean biomass. All these trends indicate that production was dominated by biomass, and not growth rates, which were much more constrained. Further, it appears that for high biomass, growth rates declined, probably as light or nutrients or both become limiting (Fig. 4b).

\section{Bioreactor Types}

Production rates for open ponds and raceway bioreactors had lower variances than closed bioreactors and significantly lower mean production $\left(\chi^{2}=70.7, P<0.0001\right)$ compared to the higher production rates in closed bioreactors (Fig. 5a), which was also found by Williams and Lauren [199]. However, variances for production in the five types of closed bioreactors were not different, and neither were their mean production rates (Fig. 5b), (df = 156, $F=0.849, P=0.496$ ).

Unfortunately, few algal species have been grown in all types of closed bioreactors making comparisons difficult.
For species that have been cultured in more than one bioreactor type, statistical analysis was hampered by low samples size for one or more bioreactor types. Therefore, in some cases, species were grouped into classes to increase sample size to make comparisons possible. Figure 6 shows that production across algal classes was not statistical different in either open (df $=194, F=0.7105, P=0.5468)$ or closed systems (df $=191, F=0.7105, P=0.547)$. As in Fig. 5a, closed bioreactors had significantly higher production than open systems, independent of algal class $(\mathrm{df}=297, F=3.529$, $P=0.001$ )

Comparing production for bioreactor type (Fig. 7), the only statistical difference was in the horizontal tubular reactors (HTR), where Chlorella production was significantly higher than cyanobacteria production $(\mathrm{df}=42$, $F=7.182, P=0.001)$. Species means for flat plates $(\mathrm{df}=42, F=0.569, P=0.638)$, VTR $(\mathrm{df}=23$, $F=1.24, P=0.309)$, and helical tubes $(\mathrm{df}=6$, $F=1.087, P=0.985$ ) were not significantly different. When comparing production within a species cultured in different bioreactors, only Chlorella had a mean $P$ significantly larger for HTR than for FP and VTR ( $\mathrm{df}=33$, $F=5.641, P=0.008)$. No differences in $P$ were determined for diatoms ( $\mathrm{df}=25, F=0.900, P=0.4567$ ), Nannochloropsis $(\mathrm{df}=17, t=1.663, P=0.114)$, cyanobacteria ( $\mathrm{df}=13, t=1.666, P=0.119)$, or Tetraselmis ( $\mathrm{df}=16, t=2.1767, P=0.0443$ ) cultured in different bioreactors. Generally, it seems that most microalgae grow equally well in most bioreactors.

Looking at the effects of physical characteristics of bioreactors, production rate was inversely related to the volume of the bioreactor (Fig. 8a) and directly proportional to surface area (not shown). The relationships for production were statistically significant at the $95 \%$ level $(\mathrm{df}=256, F=16.585$, $P<0.0001)$ for both volume and surface area of the bioreactors (Table 9). Interestingly, production varied directly with surface to volume ratio (Fig. 8b), though the trend had a lower correlation coefficient $\left(r^{2}=0.0484, \mathrm{df}=265, F=4.73\right.$, $P=0.030$ ). There was a significant difference in production
Table 5 Regressions of biomass ( $\mathrm{g} \mathrm{L}^{-1} \mathrm{dwt}$ ) for bioreactor cultures and lab and ocean populations

\begin{tabular}{|c|c|c|c|c|c|c|c|c|}
\hline & $F$ & $P$ & SS & $n$ & $\log a$ & $a$ & $b$ & $r^{2}$ \\
\hline Culture systems & 0.59 & 0.44 & 0.166 & 249 & -0.942 & 0.114 & -0.018 & 0.006 \\
\hline Packed cells ${ }^{\mathrm{a}}$ & & & & & 2.987 & 970.6 & -0.288 & \\
\hline Lab. cultures ${ }^{\mathrm{b}}$ & & & & & -0.524 & 0.299 & -0.078 & \\
\hline N. Pacific Gyre ${ }^{c}$ & & & & & -6.143 & $7.2 \times 10^{-7}$ & -0.112 & \\
\hline Tropical Atlantic ${ }^{\mathrm{d}}$ & & & & & -5.824 & $1.5 \times 10^{-6}$ & -0.348 & \\
\hline
\end{tabular}

${ }^{\text {a }}$ Based on Table 6

${ }^{\mathrm{b}}$ Cells L ${ }^{-1}$ from Agusti and Kalff [213] converted to biomass, in $\mathrm{g} \mathrm{L}^{-1}$, using g cell ${ }^{-1}$ from Strathmann [207]

${ }^{\mathrm{c}}$ Biomass from Rodríguez and Mullin [214] converted to $\mathrm{g} \mathrm{L}^{-1}$ from Strathmann [207]

${ }^{\mathrm{d}}$ Cells L ${ }^{-1}$ from Huete-Ortega et al. [215] converted to biomass, in $\mathrm{g} \mathrm{L}^{-1}$, using g cell ${ }^{-1}$ from Strathmann [207] 


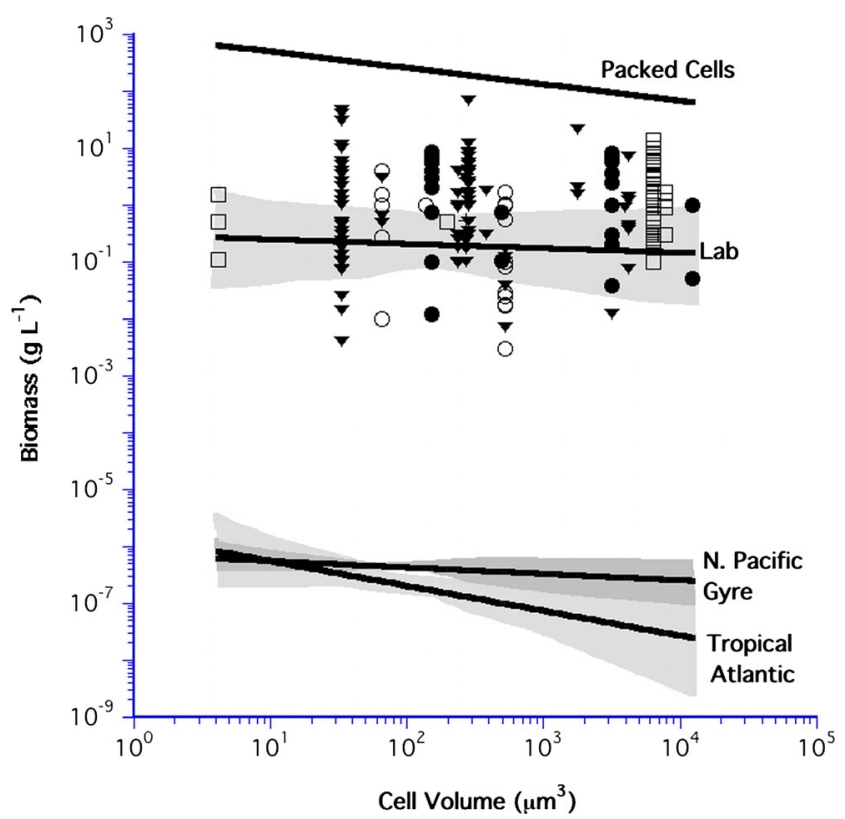

Fig. 3 Biomass for culture systems for cyanobacteria ( $\square)$, coccolithophores $(\circ)$, diatoms $(\bullet)$, green algae $(\boldsymbol{\nabla})$, and other $(+)$ relative to limits of biomass for packed cells and populations in oceans and the laboratory. Confidence intervals are plotted at the $95 \%$ level

for open systems and three of the closed bioreactors (VTR, HTR, and FP) with the flat plates having the highest production rates (Table 10).

Bioreactor volume and illuminated surface area (SA) are physical variables that depend on the design of the culture system. Both directly affect production, and thus oil yield. For instance, a production rate of $1 \mathrm{~g} \mathrm{~L}^{-1}$ day $^{-1}$ in a $10^{2}$ - $\mathrm{L}$ bioreactor would yield a biomass of $10^{2} \mathrm{~g} \mathrm{day}^{-1}$, while the same production rate in a $10^{6}$-L pond would yield $10^{6} \mathrm{~g}_{\text {day }}{ }^{-1}$. Surface area of the culture system is important since it determines the photon flux to the cultures, while the ratio of surface to volume relates to the light path.

Figure 9a shows that surface area was highly dependent on the volume of the bioreactor $(\mathrm{df}=265, F=1360, P<0.0001)$ with most of the variance accounted for by the volume $\left(r^{2}=0.880\right)$. However, this increase in surface area was accompanied by a reduction in the surface to volume ratio, which decreased from about $10^{2}: 1$ to $<1: 1 \mathrm{~m}^{2} \mathrm{~m}^{-3}$. This change in the surface to volume ratio is more clearly shown in Fig. 9b

\section{Predicted Oil Yield}

The oil yield from algal cells depends not only on production rate and culture volume but also on the mass of lipid droplets in the cells (species-specific) and the efficiency of extracting them. Yield is given by:

Yield $=P V S_{\mathrm{o}} e_{\mathrm{o}} \rho_{\mathrm{oil}}^{-1}$

where Yield is oil in $\mathrm{L} \mathrm{day}^{-1}, P$ is production $\left(\mathrm{g} \mathrm{L}^{-1}\right.$ day $\left.^{-1}\right), V$ is culture volume (L), $S_{\mathrm{o}}$ is oil storage as percent biomass, $e_{\mathrm{o}}$ is extraction efficiency, and $\rho_{\text {oil }}$ is the oil density. By keeping species-specific oil storage constant and extraction efficiency fixed, it is possible to compare oil yields based only on bioreactor characteristics. Oil yields were calculated based on $P$ and $V$ for bioreactors under the assumptions that $30 \%$ of the biomass was oil [192], the wet extraction efficiency was $70 \%$ [218], given an algal wet weight to dry weight of 12-fold [219], and $\rho_{\text {oil }}$ was $900 \mathrm{~g} \mathrm{~L}^{-1}$. Of course, more efficient downstream processing and use of algal strains with higher oil content or optimal fatty acid profiles would give higher oil yields; however, since this review is focused on bioreactor processes, these topics are beyond the scope of this paper. Further, a statistical analysis of fatty acids across species and bioreactor type would be handicapped by few data points, since this type of data has only recently been published as a result of new and improved analytical techniques.

Oil yield was highly correlated to culture volume, such that larger volumes yielded more oil (Fig. 10a), which was opposite to the trend in production, which decreased with increasing bioreactor volume (Fig. 8a). However, oil yield decreased with increasing surface to volume ratio (Fig. 10b).

Productivity and yield were categorized into four groups of bioreactors: (1) higher yield and lower production (28\%); (2) higher yield and higher production (11\%); (3) lower yield and
Table 6 Characteristics of cell sizes in a 1-L culture volume

\begin{tabular}{llll}
\hline Cell diameter $(\mu \mathrm{m})$ & \begin{tabular}{l} 
Cell volume $_{\left(\mu \mathrm{m}^{3} \text { cell }^{-1}\right)}^{\mathrm{a}}$ \\
\hline 1
\end{tabular} & $\begin{array}{l}\text { Packed concentration }^{\mathrm{b}} \\
\left(\text { cells L }^{-1}\right)\end{array}$ & $\begin{array}{l}\text { Packed cell biomass }^{\mathrm{c}} \\
\left(\mathrm{g} \mathrm{L}^{-1}\right)\end{array}$ \\
\hline 10 & 0.52 & $1.9 \times 10^{15}$ & $5.8 \times 10^{2}$ \\
$10^{2}$ & $5.2 \times 10^{1}$ & $1.9 \times 10^{13}$ & $1.6 \times 10^{2}$ \\
$10^{3}$ & $5.2 \times 10^{3}$ & $1.9 \times 10^{9}$ & $4.1 \times 10^{1}$ \\
\hline
\end{tabular}

${ }^{\text {a }}$ For spherical cells, $V_{\text {cell. }}=\pi d^{3} / 6$, where $d$ is the diameter in $\mu \mathrm{m}$

${ }^{\mathrm{b}}$ For $C$ packed, calculated as $10^{15} \mu^{3} \mathrm{~L}^{-1} / V_{\mathrm{c}}$

${ }^{\mathrm{c}}$ Biomass calculated from Strathmann [207] as $B_{\mathrm{c}}\left(\mathrm{g} \mathrm{cell}^{-1}\right) \times C\left(\right.$ cells L $\left.{ }^{-1}\right)$ 
Table 7 ANCOVA results for biomass $(B)$ by class, growth rate, and binned cell volume

\begin{tabular}{lrrrll}
\hline Source & df & \multicolumn{1}{l}{ SS } & \multicolumn{1}{l}{ MS } & \multicolumn{1}{l}{$F$} \\
\hline Model & 5 & 759.12 & 151.825 & 2.475 & 0.033 \\
Error & 236 & $14,475.20$ & 61.336 & & \\
Total & 241 & $15,234.30$ & & & \\
& & & & $t$ & $P$ \\
Cell volume & 241 & 0.000 & & -1.217 & 0.225 \\
Growth rate & 241 & 0.415 & & -2.459 & 0.015 \\
Cyano $B$ & 241 & 1.752 & & -0.568 & 0.571 \\
Cocco $B$ & 241 & 1.999 & & -1.179 & 0.240 \\
Diatom $B$ & 241 & 1.545 & & -0.976 & 0.330 \\
Green B & 241 & 0.000 & & & \\
\hline
\end{tabular}

higher production (37\%); and (4) lower yield and lower production $(24 \%)$. Figure 11a shows the grouping based on these four criteria, where high yield is assumed to be $\geq 1 \mathrm{~L} \mathrm{day}^{-1}$ and high production to be one-tenth of the theoretical maximum (i.e., $\geq 0.4 \mathrm{~g} \mathrm{~L}^{-1} \mathrm{day}^{-1}$ ), which was true for all bioreactors except for six ponds that had higher production but were clearly not clustered with group 2 , and hence were assigned to group 1 .

Only $36 \%$ of the bioreactor systems achieved yields $>1 \mathrm{~L} \mathrm{day}^{-1}$; thus, most of the bioreactors were low yield. Bioreactors with large aerial footprints (i.e., ponds, raceways, and horizontal tubular systems) dominated group 1 (89\%). Group 2 was composed of closed bioreactors or intermediate size, except for one small (2200 L) raceway pond. Group 3 was mostly small, closed bioreactor systems, and group 4 had a mix of bioreactor types and sizes.

The group median (mean) volumes were as follows: group $1,10^{5} \mathrm{~L}\left(8 \times 10^{7} \mathrm{~L}\right)$; group 2, $395 \mathrm{~L}(665 \mathrm{~L})$; group 3, $33 \mathrm{~L}$ $(85 \mathrm{~L})$; and group 4, $200 \mathrm{~L}(3780 \mathrm{~L})$. Excluding raceway ponds, the closed bioreactors in the group 2 had volumes

Table 8 ANCOVA results for production $(P)$ by class, biomass, growth, and binned cell volume

\begin{tabular}{lrrrll}
\hline Source & df & \multicolumn{1}{l}{ SS } & MS & $F$ & $P$ \\
\hline Model & 6 & 236.77 & 39.46 & 16.25 & $<0.0001$ \\
Error & 234 & 568.28 & 2.429 & & \\
Total & 240 & 805.05 & & & \\
& & & & $t$ & $P$ \\
Cell volume & & 0.000 & & -0.604 & 0.546 \\
Biomass & & 0.013 & & 5.558 & $<0.0001$ \\
Growth rate & & 0.083 & & 7.041 & $<0.0001$ \\
Cyano $P$ & & 0.352 & & 2.652 & 0.009 \\
Cocco $P$ & & 0.398 & & 0.743 & 0.458 \\
Diatom $P$ & & 0.315 & & 1.616 & 0.107 \\
Green $P$ & & 0.000 & & & \\
\hline
\end{tabular}

ranging from 140 to $1400 \mathrm{~L}$ and surface to volume ratios of up to $10^{2}: 1$, as indicated by the shaded region in Fig. $11 \mathrm{~b}$.

Of the 19 closed bioreactors in the group 2, about $50 \%$ had surface to volume ratios of approximately $10^{2}$ or higher. Of these ten bioreactors with high SA: $V$, four were horizontal tubular reactors (HTR), four were helical, one was a vertical tubular (VTR), and one was an inclined cascade. The horizontal tubular system and inclined cascade were bioreactor systems that require large horizontal surfaces to optimize the bioreactor-illuminated surface area relative to the nadir angle of the sun, and therefore, they had large aerial footprints. Helical systems had high illuminated surface areas but also had a large footprint resulting from the extensive curvature of the tubes around an inner column, which was not part of the bioreactor volume, meaning it is an unproductive part of the footprint. The smallest aerial footprint was the vertical tubular bioreactor since its cylindrical column, which is the productive core of the bioreactor, was tall but had a small diameter. Several other reactors exhibited high surface to volume ratios (i.e., flat plates); however, these had smaller volumes or lower production rates (Fig. 11b).

\section{Conclusions}

\section{Algae Diversity}

Over the nearly 200 years that algae have been studied, their taxonomy is still being altered, which makes tallying the number of species difficult [205]. Despite the difficulties in assessing algal characteristics, the Algal Database lists over 135,000 species [220] of which seaweeds are included, and some species may have duplicate taxonomic names. In all, there are 15 distinct phyla of algae.

Despite the large number and diversity of microalgal species, few have been grown in larger $(\geq 3 \mathrm{~L})$ bioreactors. Thus, the 35 genera represented here are only a small fraction of the known microalgal species, and even these species have different genomes with varied traits. Early work by the Aquatics Species Program studied nearly 3000 algal species but only 300 were cultivated [61]. In 2008, the Food and Agricultural Organization estimated that 40 species were used commercially [221] worldwide, although Terdici et al. [222] reported 10 species were commercial harvested in large bioreactors.

There are many types of photosynthetic organisms that could be used to produce vegetable-like oils including macrophytes, aquatic vascular plants, phytobenthos, as well as phytoplankton, which inhabit freshwater, marine, and terrestrial environments. One of the difficulties in finding data on these oil-producing plants and algae is that studies are distributed between different disciplines, the predominant ones being: oceanography which is concerned with marine species; limnology which focuses on freshwater species; phycology which looks at physiology and 

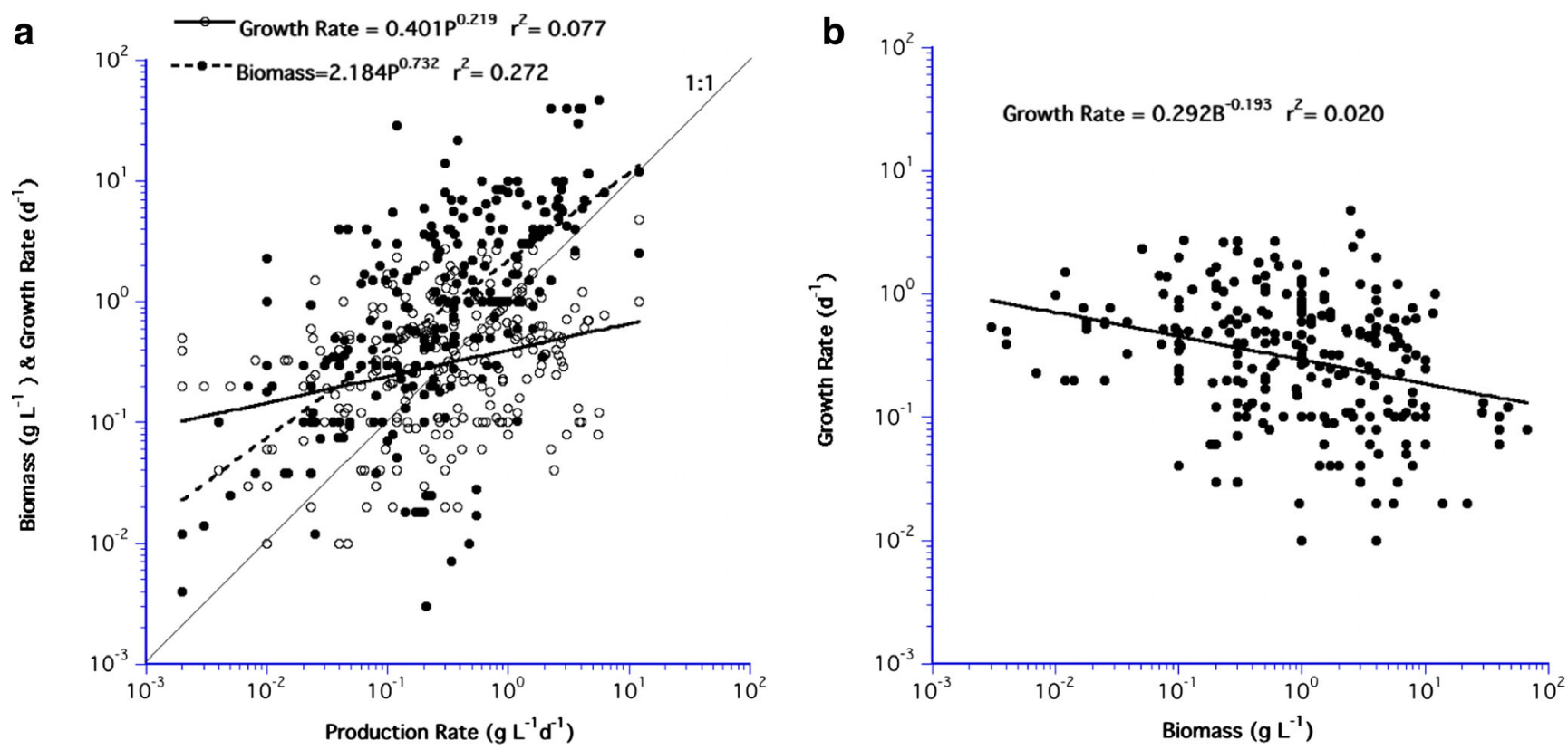

Fig. 4 The relationships between a production rate based on biomass $(\bullet)$, and growth rate $(\circ)$ and $\mathbf{b}$ growth rate versus biomass. The dashed line is the slope for biomass; the heavy, solid line for growth rate. The light, solid line represents the 1:1 relationship

morphology; and applied phycology and biotechnology which study the industrial and practical aspects of algal science and bioengineering. Therefore, the search for the best oil-producing species/subspecies is disparate and far from complete. Yet, even if cell lipid storage could be doubled by more lipid-rich species or through genetic [223] or physiological [224] manipulation of cells, the overall effect on oil yield would not be as great as

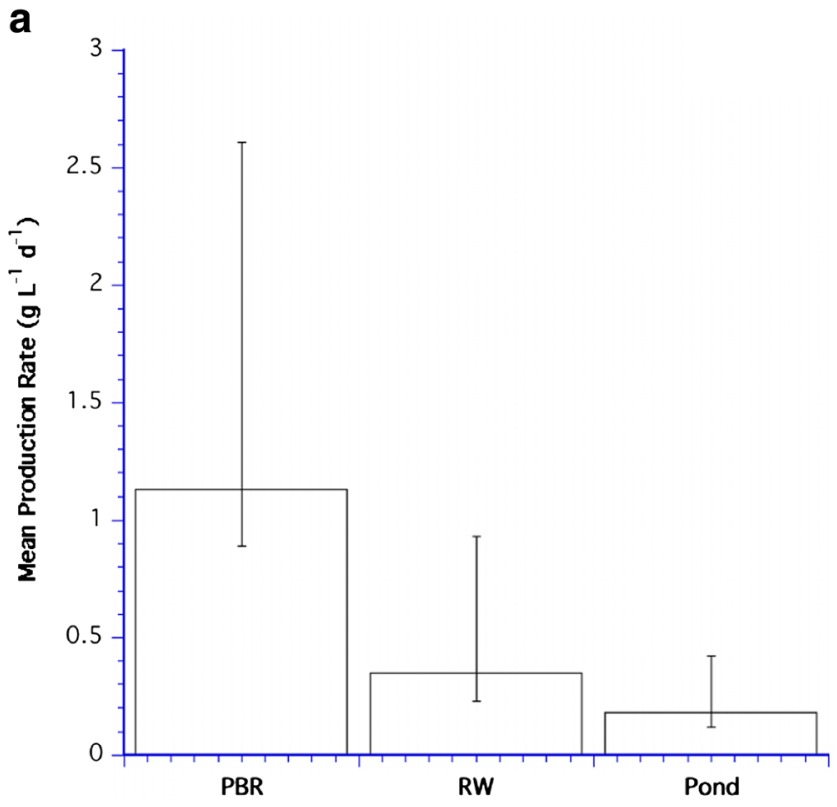

Fig. 5 Mean production rates for a photo-bioreactors (PBR), raceways (RW), and ponds; and $\mathbf{b}$ the five different types of photo-bioreactors: vertical tubular reactors (VTR), unique reactors (UBR), helical reactors, optimizing biomass concentrations and production rates, which could increase yields by tenfold or more.

\section{Growth Rate, Biomass, and Production}

Prior laboratory experiments found that maximum growth rates of microalgal cells were predominately dependent on

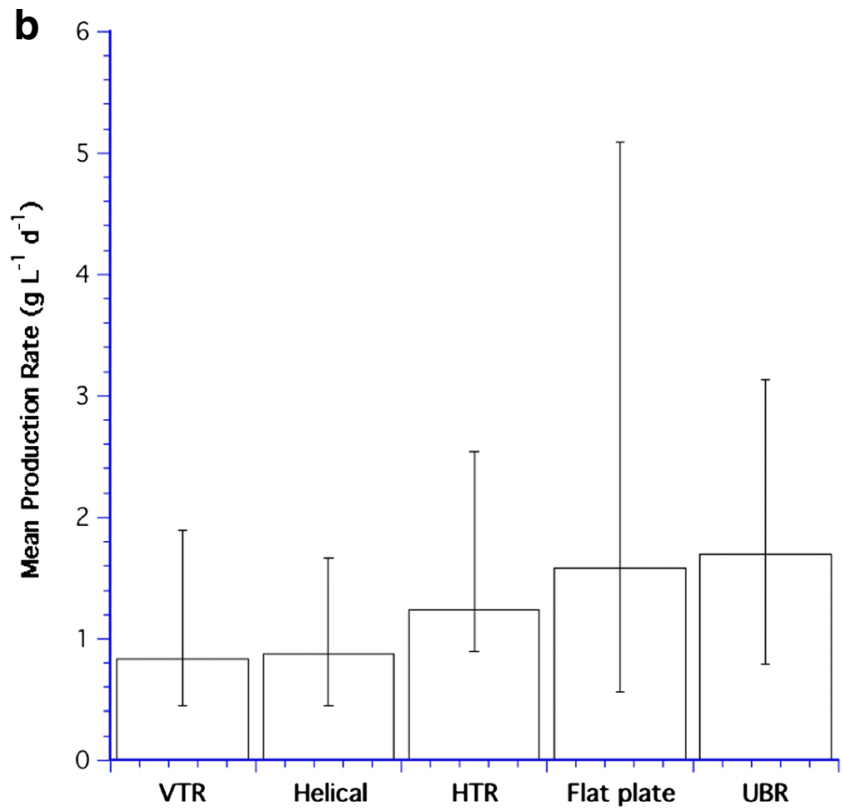

horizontal tubular reactors (HTR), and flat plate reactors (FP). The upper bar is the standard deviation, and the lower bar is two standard errors 


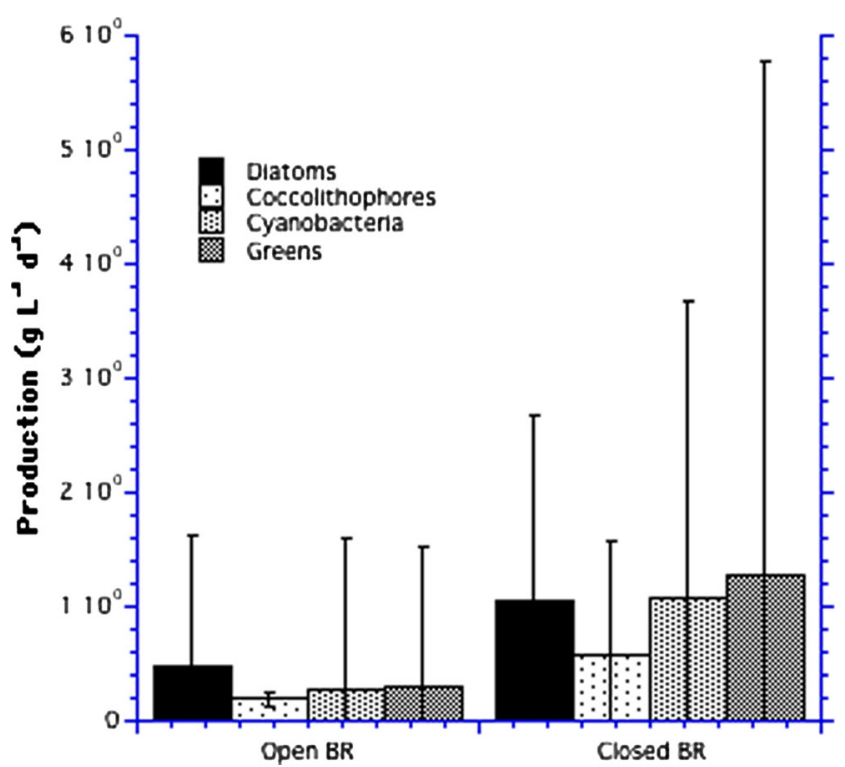

Fig. 6 Production rates for diatoms, coccolithophores, cyanobacteria, and green algae in both open and closed bioreactors (BR). Error bars are two standard deviations

the species and their cell size. In contrast, growth rates in bioreactors showed less species difference and no significant tendency to decrease with increasing cell size. The fact that growth in bioreactors varied so dramatically for the same species probably obscured any trend in growth rate with cell size. All the determinations of maximum growth in laboratory settings used only a few species, in small volumes, and with few variations in culture conditions (media, light, $\mathrm{CO}_{2}$, mixing,

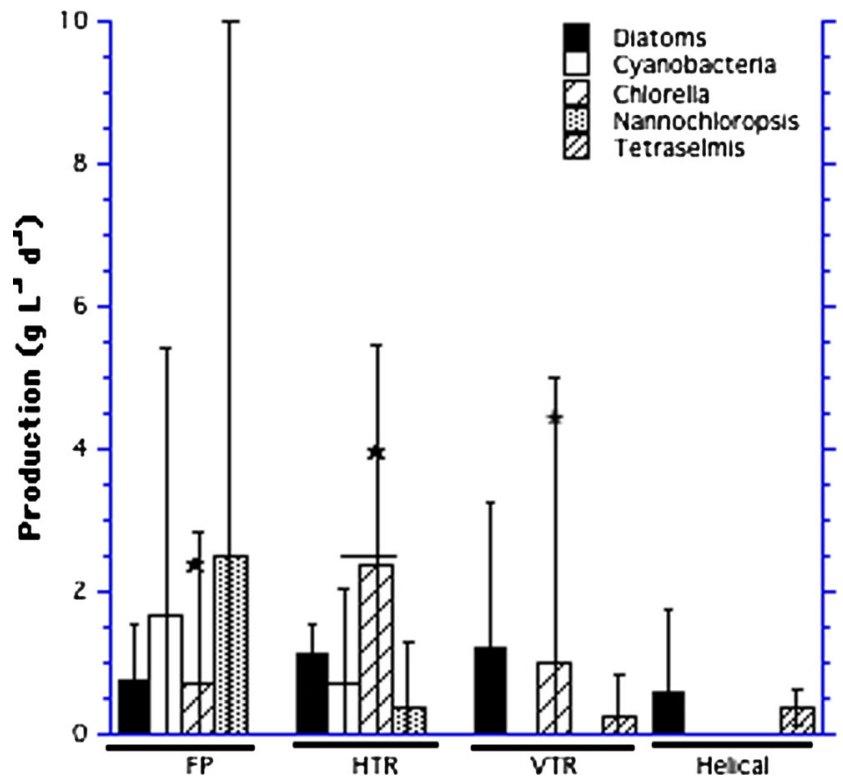

Fig. 7 Production for three green algae (Chlorella, Nannochloropsis, and Tetraselmis) cultured in flat plate (FP), horizontal tubular reactor (HTR), vertical tubular reactor (VTR), and helical reactor. Error bars are two standard deviations. Stars indicate a significant difference for Chlorella, and the bar in HTR represents a significant difference between algae cultured in the HTR etc.). In contrast, growth rates in the bioreactors were determined for many more species, over a wider variety of growth conditions. In general, the fact that growth rates in bioreactors exceeded maximal growth rates, especially for green algae and cyanobacteria, may indicate that optimum conditions occurred in these bioreactors but not for the laboratory cultures used to determine the maximum growth rates. Still, growth rates for diatoms in bioreactors were generally lower than the maximum rates, which may indicate that some bioreactors had sub-optimal growth conditions for the species cultured. It is clear that bioreactor-specific growth rates never exceed 5 day $^{-1}$, so growth rate was very confined in relation to production.

Biomass in the bioreactors was nearly constant over cell size. For all but $14 \%$ of the samples, bioreactor biomass was greater than the maximum biomass derived from laboratory data, although less than the packed concentration. The mean biomass was $3.5 \mathrm{~g} \mathrm{~L}^{-1}$ with a median value of $1.0 \mathrm{~g} \mathrm{~L}^{-1}$, and the fact that the slope of biomass versus cell size was flat means that mass was constant such that the same mass could be achieved using a large number of small cells or fewer large cells. Therefore, the selection of a target species should not necessarily depend on cell size but on growth rate, oil content, and the specific culture conditions needed to maximize the biomass.

Because population growth requires the synthesis of new biomass, $\mu_{\max }$ is closely related to metabolic rate $[225,226]$ with the same unimodal size scaling in $\mathrm{CO}_{2}$ fixation, which represents a biomass turnover rate. A unimodal size scaling of biomass-specific metabolic rate corresponds to a curvature in the log-log relationship between individual metabolic rate and body size [227, 228]. Thus, the decrease in maximum growth rates with increasing cell volume can be explained by resource limitation as a function of surface to volume ratio [212]. Because the half-saturation coefficient, $k_{\mathrm{s}}$, for nitrate uptake increases with mean spherical cell diameter, large cells with lower surface to volume ratios have higher $k_{\mathrm{s}}$, and slower nitrate uptake rates.

Chisholm [229] speculated that the maximum biomass and maximum growth rate could be related to cell nutrient requirements of microalgae. Using the diffusion limitation model of Morel et al. [230], she determined the nitrogen requirement for a spherical cell. The steady state, diffusion flux of nitrogen, with a nitrate concentration $C$ to a cell of diameter, $d$, is given by $J=2 \pi d D C$, where $D$ is the molecular diffusion coefficient of the nutrient $\left(10^{-5} \mathrm{~cm}^{2} \mathrm{~s}^{-1}\right)$. Chisholm noted that $J \geq \mu Q_{\mathrm{N}}$ was necessary for a cell to grow, where $Q_{\mathrm{N}}$ is the cell quota of nitrogen in moles $\mathrm{N} \mathrm{cell}^{-1}$. $Q_{\mathrm{N}}$ was determined from carbon content of the cell using the Redfield ratio of $16 C: N$ for cells in exponential growth and the Strathmann's equation to relate carbon content to cell volume, $\pi \mathrm{d}^{3} / 6$. Recasting $J$ in terms of 


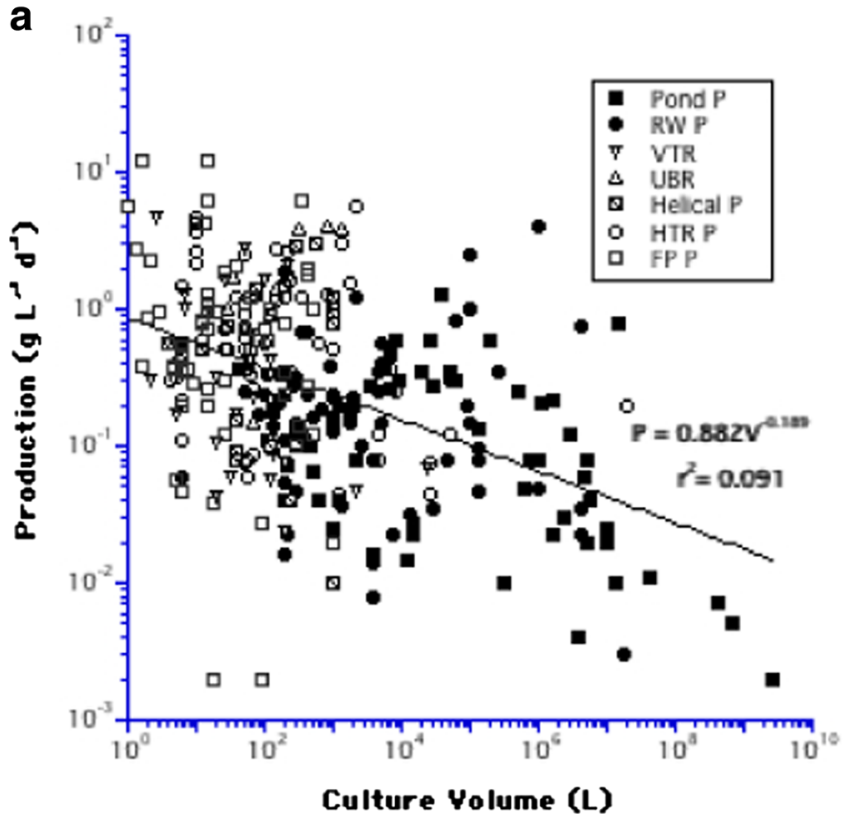

Fig. 8 a Production versus the volume of the culture system. The seven types of bioreactors systems are ponds $(\boldsymbol{\bullet})$, raceway ponds $(\mathrm{RW}, \bullet)$, vertical tubular reactors $(\mathrm{VTR}, \nabla)$, unique reactors $(\mathrm{UBR}, \Delta)$, helical

$\mu$, gives $\mu=2 \pi \mathrm{dDC} Q_{\mathrm{N}}^{-1}$ or based on cell volume, $\mu=2 \pi d D C\left(1.3 \times 10^{3} d^{2.16}\right)^{-1}$, which is proportional to $\mu \alpha$ $D C d^{1.16}$. This equation indicates that for balanced growth, the nutrient concentration must increase as cell size increases. Thus, to maintain a growth rate of 1 day $^{-1}$, smaller cells require lower concentrations of nutrients than larger cells. The maximum biomass for laboratory cultures was reached when cells were spaced roughly $10 \mu \mathrm{m}$ apart [229]. A nutrient concentration of $10^{-1} \mu \mathrm{M} \mathrm{N}-\mathrm{NO}_{3}{ }^{-}=10^{-7} \mathrm{~mol} \mathrm{~N} \mathrm{~L}^{-1}$ has $6 \times 10^{16}$ molecules in a liter $\left(6.02 \times 10^{23}\right.$ molecules $\mathrm{mole}^{-1} \times 10^{-7} \mathrm{~mol} \mathrm{~N} \mathrm{~L}^{-1}$ ) or 60 molecules in $1 \mu^{3}$. This is approximately one molecule every $0.25 \mu \mathrm{m}$. However, as the nutrient concentration increases so will the number of molecules per unit volume, thus the distance between molecules will decrease, and more molecules will be closer to the algal cell. Biomass in the bioreactors was greater than the maximum laboratory biomass and presumably was not limited by nutrients. For the high biomass concentrations in bioreactors, the

Table 9 ANCOVA for production rate on bioreactor volume and surface area

\begin{tabular}{lrrlll}
\hline Source & df & \multicolumn{1}{l}{ SS } & MS & \multicolumn{1}{l}{$F$} & \multicolumn{1}{l}{$P$} \\
\hline Model & 9 & 50.37 & 5.597 & 16.58 & $<0.0001$ \\
Error & 256 & 86.39 & 0.3371 & & \\
Total & 265 & 136.76 & & & \\
& & & & $t$ & $P>|\mathrm{t}|$ \\
Culture volume & & 0.054 & & -6.612 & $<0.0001$ \\
Surface area & & 0.059 & & 4.712 & $<0.0001$ \\
\hline
\end{tabular}

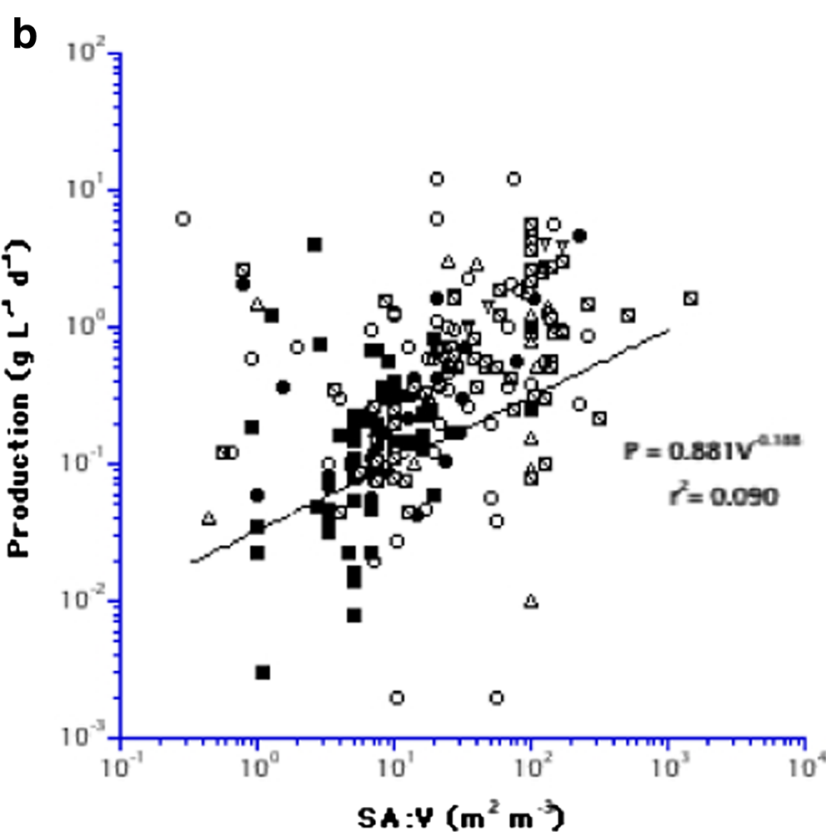

reactors $(\nabla)$, horizontal tubular reactors $(\mathrm{HTR}, \mathrm{O})$, and flat plate reactors (FP, $\square$ ); and $\mathbf{b}$ production versus the surface to volume ratio

distance between cells would decrease, and cells would be closer to nutrient molecules. This is important since the distance over which diffusion acts would be shorter, so that nutrient limitation could be avoided and growth and biomass stimulated, providing the nutrient concentration was sufficient to meet the cell's growth quota.

Diffusion-limiting conditions can also be overcome by enhancing the differential motion between the fluid and the cell $[231,232]$. This differential motion reduces the boundary layer around the cell and effectively increases the diffusion flux to the cell. The most common means of creating motions in cultures is by cell sinking $[233,234]$ and by mechanical mixing $[235,236]$.

Mixing rates and biomass also play a role in light exposure of the cells. Production has been shown to vary with high-light conditions. Increased mixing of increasingly concentrated cultures also enhances production [158, 163, 236], presumably by increasing the exposure time of the cells to the light regime. Previous to this, Laws et al. [48] increased production in a raceway pond using turbulent eddy shedding to create highfrequency fluid motions, thereby exposing cells to high-light fluctuations.

However, as biomass increases, so does attenuation of light in the bioreactor. Light attenuation can be modeled as $k=a+$ $b$, where $a$ is absorption, mostly due to algal pigments and water, and $b$ is scattering due to cell biomass and water. Mie scattering theory predicts that smaller particles scatter light at shorter wavelengths. Whitmire et al. [237] found that $b$ depended on both cells size and cell shape. They also determined that chlorophyll concentrations were highly correlated 
Table 10 ANOVA for production rate $(P)$ for bioreactor surface to volume ratio

\begin{tabular}{llllll}
\hline Source & $\mathrm{df}$ & SS & MS & $F$ & $P$ \\
\hline Total & 556 & $2,223,485$ & 3999 & 10.9611 & $<0.0001$ \\
Type & 7 & 272,647 & 38,949 & & \\
Error & 549 & $1,950,837$ & 3553 & & \\
Tukey's test & & & & \\
SA: $V$ comparison & Mean difference & $|\mathrm{q}|$ & $P$ & \\
Pond $P$ & 44.84 & 7.07 & $<0.0001$ & \\
RW $P$ & 44.68 & 8.31 & $<0.0001$ & \\
VTR $P$ & 44.19 & 5.44 & 0.0033 & \\
FP $P$ & 43.88 & 6.58 & 0.0001 & \\
HTR $P$ & 43.78 & 7.06 & $<0.001$ & \\
\hline
\end{tabular}

to $b$ for different species. Scattering by cells, however, is more concentrated in the forward direction [238] and directly proportional to cell size [239]. High pigment concentrations tend to increase $a$ in cultures which also increases with cell size [240]. Hu et al. [166] showed that the higher the cell concentration in a culture, the higher the attenuation of light, with no more than a $1 \mathrm{~mm}$ of light (at $550 \mathrm{~nm}$ ) penetration for a biomass of $15 \mathrm{~g} \mathrm{~L}^{-1}$. The optimum light path length to maintain high production for small cells was $20 \mathrm{~cm}$ [183].

Inconsistencies in biomass yields for microalgal systems are largely responsible for the economic uncertainty and unfavorable results of life cycle analyses for biofuel production [241]. However, microalgae-based biofuels also hold the future possibility for providing energy independence from fossil fuels, without compromising the use of arable lands or food production [200, 242, 243]. Benemann and Oswald [4] and Linquist et al. [243] argue that a biomass of $20 \mathrm{~g} \mathrm{~m}^{2}$ day $^{-1}$ with an oil content of $25 \%$ oil costs more than the market value, and needs to be $\geq 30 \mathrm{~g} \mathrm{~m}^{2}$ day $^{-1}$ with a content of $50 \%$ oil. For a SA: $V$ of $10^{2}: 1$ this would be $3 \mathrm{~g} \mathrm{~L}^{-1}$ day ${ }^{-1}$, which is similar to a recent estimate by Griffiths et al. [244] for cells with $50 \%$ oil content, but much lower for cells with lower oil content.

\section{Bioreactors and Scale-up}

Production in algal cultures decreases with the volume of the bioreactor, and open bioreactor systems are not as productive
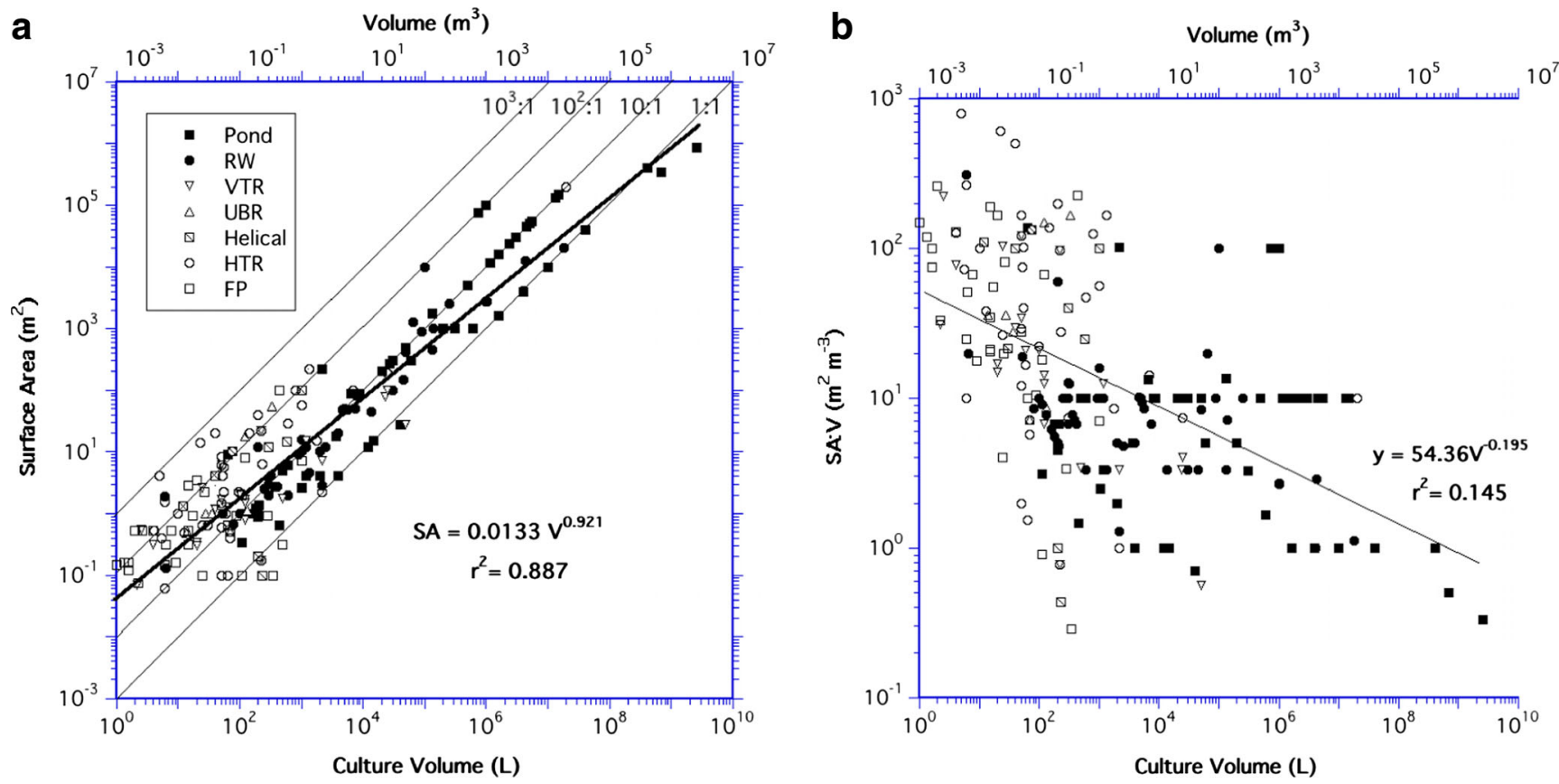

Fig. 9 Regressions for surface area on bioreactor volume (a) and surface to volume ratio of bioreactors (b). The thick line in a is the regression fit while the thin lines indicate the surface area to volume ratios from 1 to $10^{3} \mathrm{~m}^{2} \mathrm{~m}^{-3}$ 


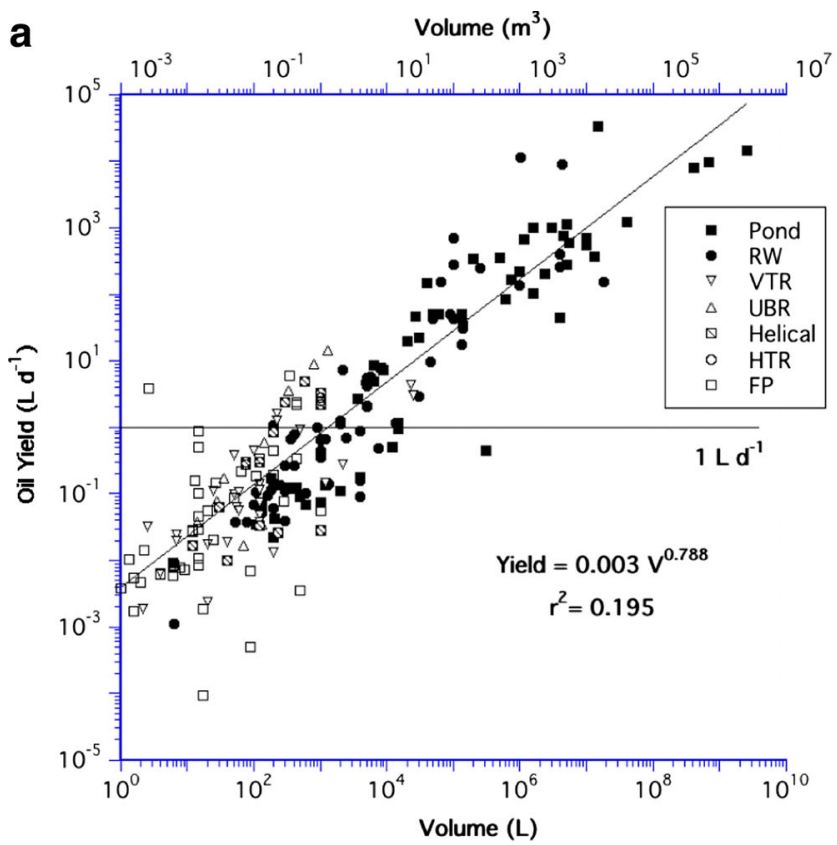

b

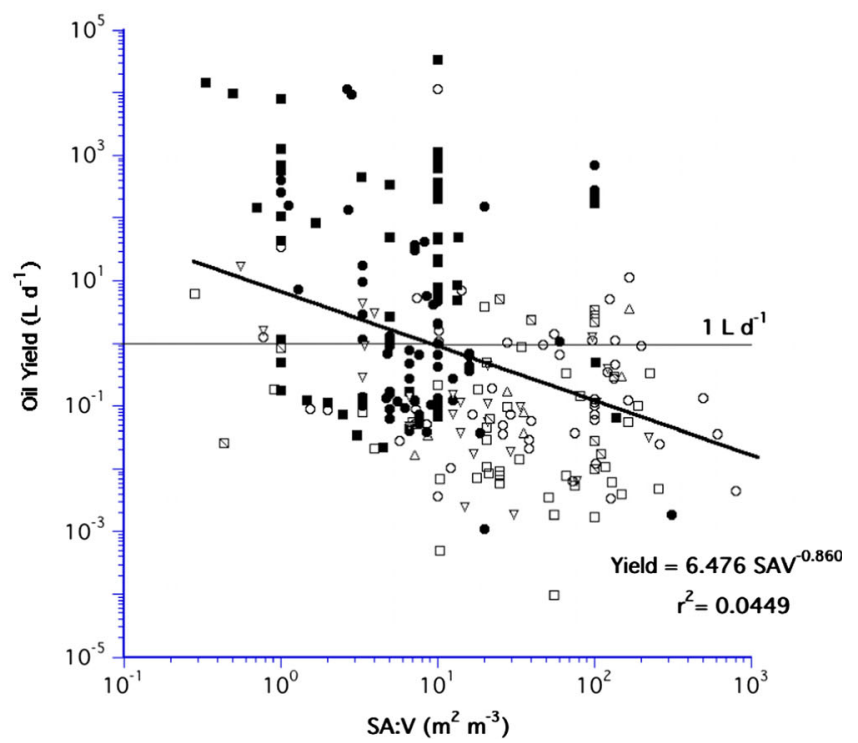

Fig. 10 Oil yields based on bioreactor: a volume; and $\mathbf{b}$ surface to volume ratio

as closed ones. However, production in different types of bioreactors may be closely associated with bioreactor volume since the median volume for open systems was $4000 \mathrm{~L}$ $(N=136)$ compared to a median volume of $55 \mathrm{~L}(N=182)$ for closed systems. There also seems to be no strong data to support that one species grows best in a specific bioreactor type. Many scientists assume that species production is

a

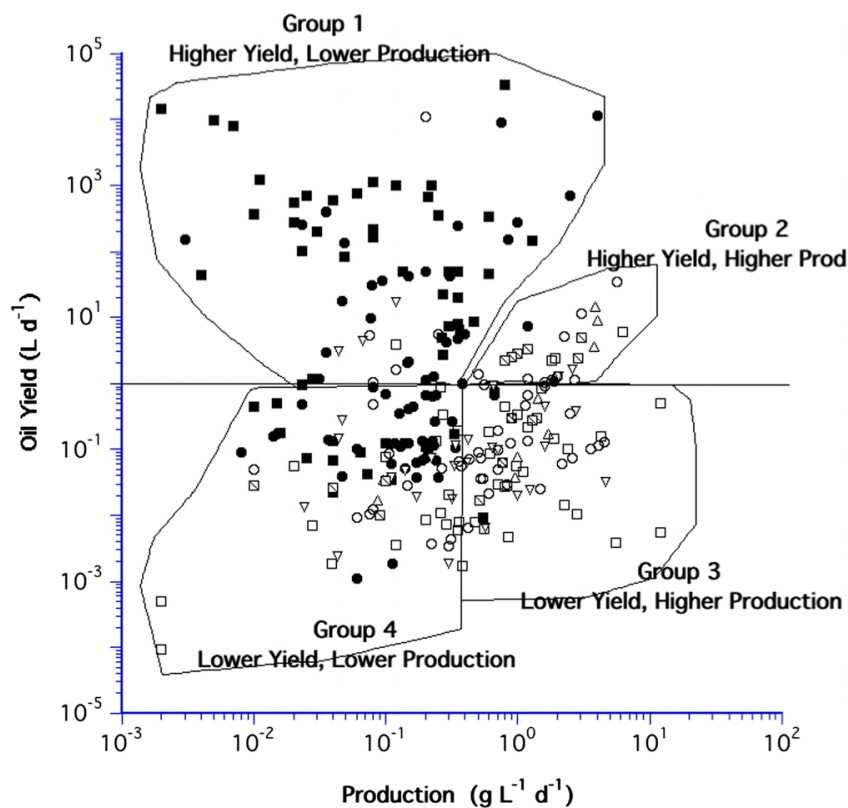

Fig. 11 a Oil yield and production for the different bioreactors (same symbols as in Fig. 8) separated in to four groups, and $\mathbf{b}$ the same groups plotted against the bioreactor surface area and volume. The shaded area dependent on bioreactor type, but this does not seem to be supported by these statistical analyses. It is more likely related to bioreactor operations.

Benemann [245] estimated $90 \%$ of microalgae production worldwide is in ponds, most of which are in China. Large ponds that produce algal biomass for biofuels often exceed $10^{5} \mathrm{~L}$. However, such systems have come under increasing

b

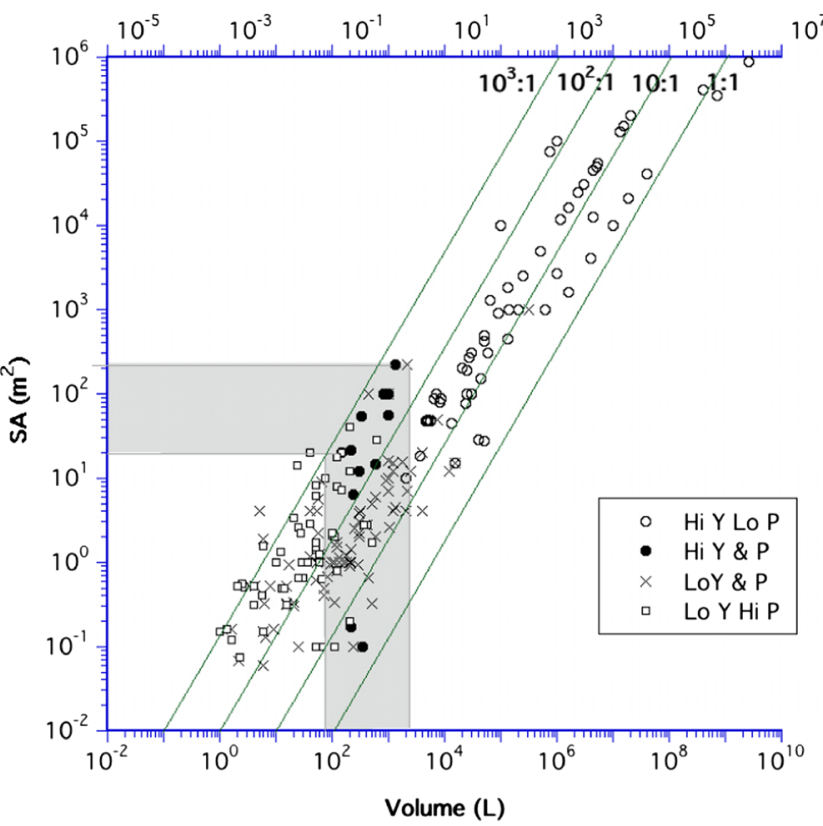

represents the range in volumes and surface areas for the closed bioreactors in the group 2 (higher yield and higher production) 
criticism for their usage of large amounts of land and water [241, 242]. Their advantage is that they do not require high production rates to produce high oil yields, only large volumes. In contrast, smaller horizontal reactors can conserve water by recycling it; however, they too have a large footprint, and because they have lower volumes $\left(10^{4} \mathrm{~L}\right)$, they require higher cell densities to achieve the same high yields as ponds. Ponds and tubular reactors have lower production but higher cell densities than algae growing in unlimited nutrient and light conditions in small $(<1 \mathrm{~L})$ laboratory cultures. This may be a result of the infamous "bottle effect" [246], or it may simply a result of contamination/competition, low light or nutrients, or inefficient mixing. Whatever the reason, it seems that larger cultures are less productive yet more concentrated than those at bench scales. This makes system scaling more unpredictable, and no practical scale-up methods exist although several design parameters have been identified, e.g., light, $\mathrm{CO}_{2}$, mixing, etc. [247-257]. Since production decreases with bioreactor volume, smaller bioreactors $\left(10^{2}-10^{3} \mathrm{~L}\right)$ may be more practical, especially if they are designed to provide high surface areas for high illumination [257, 258]. Indeed, of 317 bioreactors studies analyzed in this paper, only $8.5 \%$ had production rates $>2.5 \mathrm{~g} \mathrm{~L}^{-1}$ day $^{-1}$, and all of these bioreactors, except for two, were smaller systems with a mean volume of $322 \mathrm{~L}$, but achieved high biomass concentrations and/or growth rates by a combination of high illuminated surface areas (i.e., high SA:V) and moderate mixing with air or $1-5 \% \mathrm{CO}_{2}$. Interestingly, while air lift mixing is a cheap and an efficient means to deliver high dissolved inorganic carbon (DIC) levels to cultures and keep cells mixed, bubbles also can have a high attenuation of light and create high shear when they break. Therefore, the interplay between homogenous mixing of biomass to optimize light levels in bioreactors, air mixing to enhance DIC, and high surface to volume ratio of bioreactors needs to be explored in more detail to find the optimal conditions.

Many biofuel bioreactors, such as coils, flat plates, and cascades, have been designed to optimize the surface to volume ratio to provide high-light conditions to cells. This design promotes higher production rates, by enhancing biomass and maintaining higher growth rates. However, high production rates must be linked to high yields, which can be achieved by larger volumes. The caveat is that large volume systems with high surface to volume ratios drastically increase the footprint of the culture system, thereby competing for space with agricultural crop or high biodiversity lands, which is a major criticism of commercial algal processes. Systems with large surface areas also compete for solar radiation with other renewable energy systems, such as photovoltaics and solar water heaters. Other than higher production rates and smaller footprints, there are other advantages to small bioreactors, such as they require less energy-consuming components (e.g., one, small pump instead of many large ones) and smaller downstream-processing units. The later makes harvesting and extracting biomass from a small closed reactor simpler and less expensive than harvesting raceway ponds [259]. Thus, the combination of less power consumption, fewer materials, and higher biomass and production rates could reduce the price of algal oil, which would be another advantage of smaller bioreactors.

To overcome the problem of low yields in small bioreactor systems, the surface area being irradiated should be optimized for the minimum volume that achieves high production rates $(\geq$ $1 \mathrm{~g} \mathrm{~L}^{-1}$ day $^{-1}$ ) by maintaining high algal concentrations (e.g., $\geq 1 \mathrm{~g} \mathrm{~L}^{-1}$ ) and growth rates (e.g., 1 day $^{-1}$ ). In theory, one hundred thirty, 200-L bioreactors could attain a cumulative

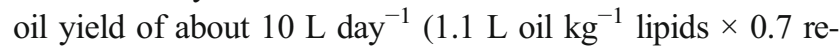
covery efficiency $\times 0.5$ lipids $\times 130$ bioreactors $\times 200 \mathrm{~L}$ biorector $^{-1} \times 10^{-3} \mathrm{~kg} \mathrm{~L}^{-1} \mathrm{day}^{-1}$ ); the same yield as half of the ponds surveyed in this paper, provided the lipid content of the cells, is around $50 \%$ of the dry weight. The number of bioreactors could be reduced to 33 if production could be maintained at the maximum level of $4 \mathrm{~g} \mathrm{~L}^{-1} \mathrm{day}^{-1}$. One approach to increase the irradiated area of a small volume bioreactor would not be to increase the exterior surface area (i.e., footprint), but increase photon flux inside the system. Internal daylighting or a dense distribution of internal lights could achieve this and also reduce the light path. If these were incorporated into a small volume vertical bioreactor, the spatial footprint would be small, minimizing the use of open space without displacing agriculture, biodiversity, or green space. Therefore, designs of future culture systems should pay closer attention to high yields and low footprints [260-265], as well as minimal energy consumption [266]. This would be especially applicable to smaller commercial volumes (i.e., $200 \mathrm{~L}$ ) with high illuminated areas and adequate mixing of cells through the light field, but not at such high turbulent levels that would increase cell mortality, and thus reduce biomass [267-269].

Acknowledgments I thank Dr. Marcel Egli for helping with the literature search and for proofing the manuscript along with Dr. Ulrike Zika. Special thanks to the HSLU Office of Researcher and Vice-Director Andrea Weber Marin for supporting this work. My deepest appreciation goes to the hundreds of researchers who produced the data used in this study and to the keen eyes and positive criticisms of two reviewers.

Open Access This article is distributed under the terms of the Creative Commons Attribution 4.0 International License (http:// creativecommons.org/licenses/by/4.0/), which permits unrestricted use, distribution, and reproduction in any medium, provided you give appropriate credit to the original author(s) and the source, provide a link to the Creative Commons license, and indicate if changes were made.

\section{References}

1. Ali S, Saleh AM (2012) Spirulina - an overview. International Journal of Pharmacy and Pharmaceutical Science 4(3):9-15

2. Ansell A, Raymont JEG, Lander KF (1963) Studies on the mass culture of Pherodactylum. III: small-scale experiments. Limnol Oceanogr 8(2):207-213 
3. Beck L, Oswald WJ, Goldmand JC (1971) Removal of nitrate by an algal system-phase II, bio-engineering aspects of agricultural drainage San Joaquin Valley California removal of nitrate by an algal system. Water Pollution Control Research Series 1:3030 ELY3006/3037I-I3033

4. Benemann J, Oswald WJ (1996) Systems and economic analysis of microalgae ponds for conversion of $\mathrm{CO}_{2}$ to biomass. Final Report DOE, Pittsburg Energy Tech Center United States. UNT Digital Library. http://digital.library.unt.edu/ark:/67531 /metadc680796/

5. Benemann J, Koopman BL, Weissman JC, Eisenberg M, Oswald WJ (1977) Cultivation on sewage of microalgae harvestable by microstrainers. Progress Report, US Dept of Energy TID 27702 April (1977)

6. Benemann J, Tillett BM (1987) Effects of fluctuating environments on the selection of high yielding microalgae. Final report Solar Energy Research Institute:subcontract xk-4-04136-04106

7. Benemann J, Weissman JC, Eisenberg M, Koopman BL, Grebol R, Caskey RD, Thompson R, Oswald WJ (1978) Integrated system for the conversion of solar energy with sewage grown microalgae. Final report sanitary engineering research lab. University of California, Berkeley

8. Benson B, Rusch KA (2005) Investigation of the light dynamics and their impact on algal growth rate in a hydraulically integrated serial turbidostat algal reactor (HISTAR). Aquaculture Eng 35: 122-134

9. Borowitzka MA, Moheimani NR (2013) Open pond culture systems. In: Borowitzka MA, Moheimani NR (eds) Algae for Biofuels and Energy, Developments in Applied Phycology, 5, Springer, pp 133-152

10. Catawatcharakul N (1994) Development of a tubular photobioreactor for mass cultivation of Spirdina platensis. Thesis, King Mongkut's Institute of Technology

11. D'Elia C, Ryther JH, Losordo TM (1977) Productivity and nitrogen balance in large scale phytoplankton cultures. Water Res 11(12):1021-1096

12. Dodge C (1978) Aquaculture in the Soviet Union (1976). From Goldman JC Fuels from solar energy: photosynthetic systemsstate of the art and potential for energy production. Final report, The US Department of Energy, Contract EG-77-S-02-4151

13. Fagiri Y, Salleh A, El-Nagerabi SAF (2013) Influence of chemical and environmental factors on the growth performance of Spirulina platensis strain SZ100. J Algal Biomass Utln 4(2):7-15

14. Goldman J (1978) Fuels from solar energy: photosynthetic systems - state of the art and potential for energy production. Final report The Department of Energy, Contract EG-77-S-02-4151

15. Grobbelaar J (1992) Potential of algal production. Water SA South Africa 8(2):79-85

16. Gromov B, Pinevich VV (1978) Investigations of blue-green algae associated with some aspects of their mass cultivation. (1972) From Goldman JC Fuels from solar energy: photosynthetic systems - state of the art and potential for energy production. Final report, The US Department of Energy, Contract EG-77-S-02-4151

17. Gummert F, Meffert E, Stratmann H (1953) Nonsterile large-scale culture of Chlorella in greenhouse and open air. In: Burlew JS (ed) Algal culture from laboratory to pilot. Carnegie Institution of Washington Publications, Washington, pp. 166-176

18. Haglund K, Pedersén M (1993) Outdoor pond cultivation of the subtropical marine red alga Gracilaria tenuistipitata in brackish water in Sweden. Growth, nutrient uptake, co-cultivation with rainbow trout and epiphyte control. J Appl Phycology 5(3):271284

19. Mayer M, Zuri U, Shain Y, Ginzburg H (1964) Problems of design and ecological considerations in mass culture of algae. Biotechnol Bioeng 4:173-190
20. Morimura Y, Nihei T, Sasa T (1955) Outdoor bubbling culture of some unicellular algae. J Gen Appl Microbiol 1(3):173-182

21. Necas O, Lhotsky O (1967) Annual report of the Laboratory of Experimental Algology and Department of Applied Algology for the year 1966. Czech Acad Sci Instit Microb Trebon, Czech

22. Price E (1969) Genesis and scope of interagency cooperative studies of control of nitrates in subsurface agricultural waste waters. Collected papers regarding nitrates in agricultural waste water, Water Pollution Control Resource Series 13030EL1 12/69. U.S. Govt Printing Office, Washington DC

23. Setlik J, Sist V, Malek I (1978) Algology studies. Trebon 1:111164. From Goldman, JC Fuels from solar energy photosynthetic systems; state of the art and potential for energy production, Final report, The US Department of Energy, Contract EG-77-S-02-4151

24. Shelef G, Schwartz M, Schechter H (1973) Prediction of photosynthetic biomass production in accelerated algal-bacterial wastewater treatment systems. In: Jenkins SH (ed) Advances in water pollution research. Pergamon Press, Oxford, pp. 181-189

25. Shelef G (1978) Personal Communication. From Goldman JC, Fuels from solar energy: photosynthetic systems - state of the art and potential for energy production. Final report:, The US Department of Energy, Contract EG-77-S-02-4151

26. Shelef G, Moraine R, Berner T, Levi A, Oron G (1978) Solar energy conversion via algal wastewater treatment and protein production. In: Hall DO, Coombs J, Goodwin TW (eds) Proc 4th international congress on photosynthesis. Biochem Soc, London, pp. 657-675

27. Shurtleff W (1978) Personal Communication. From Goldman JC Fuels from solar energy: photosynthetic systems - state of the art and potential for energy production. Final report, The US Department of Energy, Contract EG-77-S-02-4151

28. Soeder C (1976) Mass culture of Chlorella in Asian countries. Naturwissenschaften 63:131-138

29. Tsukada O, Kawahara T, Miyachi S (1977) Mass culture of Chlorella in Asian countries. In: Mitsui A, Miyachi S, San Pietro A, Tamura S (eds) Biological solar energy conversion. Academic Press, New York, pp. 363-365

30. Watanabe A, Hattori A, Fujita Y, Kiyohara T (1959) Large scale culture of a blue-green algae Tolypothrix tenuis utilizing hot spring and natural gas as heat and carbon dioxide sources. J Gen Appl Microbiol 5:51-57

31. Green BF, Berstone LS, Linquist TJ, Oswald WJ (1996) Advanced integrated wastewater pond systems for nitrogen removal. Water Sci Technol 33(7):207-217

32. Ciferri O, Tiboni O (1985) The biochemistry and industrial potential of Spirulina. Annu Rev Microbiol 39:503-526

33. Craggs R, Heubeck S, Lundquist TJ, Benemann RJ (2011) Algal biofuels from wastewater treatment high rate algal ponds. Water Sci Technol 63(4):660-665. doi:10.2166/wst.2011.10

34. Rao R, Ravishankar GA, Sarada R (2012) Cultivation of green alga Botryococcus braunii in raceway, circular ponds under outdoor conditions and its growth, hydrocarbon production. Bioresour Technol 123:528-533

35. Converti A, Lodi A, Del Borghi A, Solisio C (2006) Cultivation of Spirulina platensis in a combined airlift-tubular reactor system. Biochemical Eng J 32(1):13-18

36. Crowe B, Attalah S, Agrawal S, Waller P, Ryan R, Van Wagenen J, Chavis A, Kyndt J, Kacira M, Ogden KL, Huesemann M (2012) A comparison of Nannochloropsis salina growth performance in two outdoor pond designs: conventional raceways versus the ARID pond with superior temperature management. International $\mathrm{J}$ Chemical Eng 2012:1-9. doi:10.1155/2012/920608

37. Doucha J, Lívanský K (1995) Novel outdoor thin-layer high density microalgal culture system: productivity and operational parameters. Algol Stud 76:129-147

38. Fournadzhieva S, Bojadgieva K, Pilarski P (2003) Bulgarian experience in aquaculture (microalgae) — cultivation, production and 
development. European Geothermal Conference Szeged, Hungary, 25-30 May

39. Garcia-Gonzalez M, Moreno J, Canavate JP, Anguis V, Prieto A, Manzano C, Florencio FJ, Guerrero MG (2003) Conditions for open-air outdoor culture of Dunaliella salina in Southern Spain. J Appl Phycol 15(2-3):177-184

40. Göksan T, Zereriyaoğlu A, Ak I (2007) The growth of Spirulina platensis in different culture systems under greenhouse condition. Turk J Biol 31:47-52

41. Hase R, Oikawa H, Sasao C, Morita M, Watanabe Y (2000) Photosynthetic production of microalgal biomass in a raceway system under greenhouse conditions in Sendai City. J Biosci Bioeng 89(2):157-163

42. Huesemann M, Hausmann TS, Bartham R, Aksoy M, Weissman JC, Benemann JR (2008) Biomass productivities in wild type and pigment mutant of Cyclotella sp (diatom). Appl Biochem Biotechnol 157(3):507-526

43. Vonshak A, Richmond A (1988) Mass production of Spirulina: an overview. Biomass 15:233-248

44. Iliev I, Petkov G, Lukavsky J, Furnadzhieva S, Andreeva R, Bankova V (2010) The alga Trachydiscus minutus (Pseudostaurastrum minutum), growth and composition. General and Applied Plant Physiology 36(3-4):222-231

45. Jiménez C, Cossío BR, Labellal D, Niell FX (2003) The feasibility of industrial production of Spirulina (Arthrospira) in Southern Spain. Aquaculture 217:179-190

46. Kasiri S, Ulrich A, Prasad V (2015) Optimization of $\mathrm{CO}_{2}$ fixation by Chlorella kessleri cultivated in a closed raceway photo-bioreactor. Biores Technol 194:144-155

47. Laws E (1985) Shallow algal mass culture systems for the production of oils. Final Report, Solar Energy Research Institute

48. Laws E, Taguchi S, Hirata J, Pang L (1986) Optimization of microalgal production in a shallow outdoor flume. Biotechnol Bioeng 28:191-197

49. Matsumoto H, Shioji N, Hamasaki A, Ikuta Y, Fukuda Y, Sato M, Endo N, Tasukamoto T (1995) Carbon dioxide fixation by microalgae photosynthesis using actual flue gas discharged from a boiler. Appl Biochem Biotechnol 51-52:681-692

50. Moazami N, Ashon A, Ranjbar R, Tangestani M, Eghtesadi R, Nejad AS (2013) Large-scale biodiesel production using microalgae biomass of Nannochloropsis. Biomass Bioenergy 39: 449-453

51. Moheimani N, Borowitzka MA (2007) Limits to production of the alga Pleurochrysis carterae (Haptophyta) grown in outdoor raceway ponds. Biotechnol Bioeng 96(1):27-36

52. Moheimani N, Borowitzka MA (2006) The long-term culture of the coccolithophore Pleurochrysis carterae (Haptophyta) in outdoor raceway ponds. J Appl Phycol 18(6):703-712

53. Benemann J, Goebel RP, Auenstein DC (1982) Microalgae as a source of liquid fuels. Seri/Cp-231-1808 Proceeding of the SERI Biomass Program, 20-23 June

54. Olguín E, Galicia S, Mercado G, Pérez T (2003) Annual productivity of Spirulina (Arthrospira) and nutrient removal in a pig wastewater recycling process under tropical conditions. J Appl Phycol 15:249-257

55. Oswald W (1995) Ponds in the twenty-first century. Water Sci Tech 31(12):1-8

56. Pushparaj B, Pelosi E, Carlozzi P, Torzillo G (1995) Yield and biochemical composition of a marine cyanobacterium (Nodularia sp) in outdoor culture. Aquat Microb Ecol 9:13-16

57. Pushparaj B, Pelosi E, Tredici M, Pinzani E, Materassi R (1997) As integrated culture system for outdoor production of microalgae and cyanobacteria. J Appl Phycol 9(2):113-119

58. Raes E, Isdepsky A, Muylaert K, Borowitzka MA, Moheimani NR (2014) Comparison of growth of Tetraselmis in a tubular photobioreactor (Biocoil) and a raceway pond. J Appl Phycol 26:247-255

59. Richmond A, Lichtenberg E, Stahl B, Vonshak A (1990) Quantitative assessment of the major limitations on productivity of Spirulina platensis in open raceways. J Appl Phycol 2(3):195206

60. San Pedro A, González-López CV, Acién FG, Molina-Grima E (2015) Outdoor pilot production of Nannochloropsis gaditana: influence of culture parameters and lipid production rates in raceway ponds. Algal Res 8:205-213. doi:10.1016/j. algal.2015.1002.1013

61. Sheehan J, Dunahay T, Benemann JR, Roessler P (1998) A look back at the aquatic species program. US Depart Energy NREL/TP-580-24190 TRN: US200420\%\%272 L

62. Sutherland D, Williams CH, Turnbull H, Broady PA, Craggs PJ (2013) Seasonal variation in light utilization, biomass production and nutrient removal by wastewater microalgae in full-scale highrate algal pond. J Appl Phycol 23(3):1317-1329

63. Tredici MR, Papuzzo T, Tomaselli L (1986) Outdoor mass-culture of Spirulina maxima in sea-water. Appl Microbiol Biotechnol 24: 47-50

64. Vendlove O (1969) Les problemes de la technologie de la culture des algues sur une grande echelle dans les installations au dehors. Annali Di Microbiologia 19:1-12

65. Weissman J, Tillet DM, Goebel RP (1989) Design and operation of an outdoor microalgae test facility. SERI/STR 232(3569):1-57

66. Richmond A (2004) Biological principles of mass cultivation. In: Richmond A (ed) Handbook of microalgal methods, biotechnology and applied phycology. Blackwell Science, Oxford, pp. 125177

67. Barbosa M (2003) Microalgal photobioreactors: scale-up and optimisation. Wageningen University, The Netherlands, Dissertation

68. Baynes S, Emerson L, Scott AP (1979) Production of algae for use in the rearing of larval fish. Fisheries Research Technical Report 53:13-18

69. Chae SH, Hwang EJ, Shin HS (2006) Single cell protein production of Euglena gracilis and carbon dioxide fixation in an innovative photo-bioreactor. Biores Technol 97:322-329

70. Chini Zittelli G, Rodolfi L, Tredici MR (2003) Mass cultivation of Nannochloropsis sp in annular reactors. J Appl Phycol 15:107114

71. Chini Zittelli G, Rodolfi L, Biondi N, Tredici MR (2006) Productivity and photosynthetic efficiency of outdoor cultures of Tetraselmis suecica in annular columns. Aquaculture 261(3):932943

72. Cohen E, Korin A, Arad SM (1991) A closed system for outdoor cultivation of different microalgae species. Biomass Bioenergy 2: 83-88

73. Castellanos SC (2013) Batch and continuous studies of Chlorella vulgaris in photo-bioreactors. Disseration, University of Western Ontario, Electronic Thesis and Dissertation Repository. Paper 1113

74. Eriksen NT, Geest T, Iversen JJL (1996) Phototrophic growth in the lumostat: a photo-bioreactor with on-line optimization of light intensity. J Appl Phycol 8:345-352

75. Garcia-Malea Lopez M, Del Rio SE, Casas Lopez JL, Acién Fernández FG, Sevilla JM, Rivas J (2006) Comparative analysis of the outdoorculture of Haematococcus pluvialis in tubular and bubble column photobioreactors. J Biotechnol 123(3):329-342

76. Hosseini N, Shang H, Ross GM, Scott JA (2015) Microalgae cultivation in a novel top-lit gas-lift open bioreactor. Biores Technol 192:432-440

77. Richmond A (2004) Handbook of migroalgal culture. Biotechnology and applied phycology. Blackwell Science, Oxford 
78. Kanawawa T, Fujita C, Yuhara T, Sasa T (1958) Mass culture of unicellular algae using the "open circulation method". J Gen Appl Microbiol 4:135-152

79. Mandalam R, Palsson BØ (1998) Elemental balancing of biomass and medium composition enhances growth capacity in highdensity Chlorella vulgaris cultures. Biotechnol Bioeng 59(5): 605-611

80. Martínez-Jerónimo F, Espinosa-Chavez F (1994) A laboratoryscale system for mass culture of freshwater microalgae in polyethylene bags. J Appl Phycol 6:423-425

81. Mirón AS, Gómez AC, Camacho FG, Molina Grima E, Chisti Y (1999) Comparative evaluation of compact photobioreactors for large scale monoculture of microalgae. J Biotechnol 70(249):270

82. Miyamoto K, Wable O, Benemann JR (1988) Vertical tubular reactor for microalgae cultivation. Biotechnol Letters 10(10): 703-708

83. Moheimani N (2013) Long-term outdoor growth and lipid productivity of Tetraselmis suecica, Dunaliella tertiolecta and Chlorella sp (Chlorophyta) in bag photobioreactors. J Appl Phycol 25(1): 167-176

84. Molina Grima E, Perez JAS, Camacho FG, Sevilla JMF, Fernandez FGA (1996) Productivity analysis of outdoor chemostat culture in tubular air-lift photobioreactors. J Appl Phycol 8:369-380

85. Ramanathan G, Rajarathinam K, Boothapandi M, Abirami B, Ganesamoorthy G, Duraipandi (2011) Construction of vertical tubular photobioreactor for microalgae cultivation. J Algal Biomass Utln 2(2):41-52

86. Burlew J (1953) Pilot plant experiments. In: Burlew JS (ed) Algal culture: from laboratory to pilot. Carnegie Institution of Washington Publications, Washington, pp. 1-357

87. Trotta P (1981) A simple and inexpensive system for continuous monoxenic mass culture of marine microalgae. Aquaculture 22: 383-387

88. Wang S-K, Hu Y-R, Wang F, Stiles AR, Liu C-Z (2014) Scale-up cultivation of Chlorella ellipsoidea from indoor to outdoor in bubble column bioreactors. Biores Technol 156:117-122

89. Xai L, Ge H, Zhou X, Zhang D, Hu C (2013) Photoautotrophic outdoor two-stage cultivation for oleaginous microalgae Scenedesmus obtusus XJ-15. Biores Technol 144:261-267

90. Pirt S, Panikov N, Lee YK (1979) The mini-loop, a small-scale air-lift microbial culture vessel and photobiological reactor. J Chem Technol Biotechnol 29:437-441

91. Zhou X, Xia L, Ge H, Zhang D, Hu C (2013) Feasibility of biodiesel production by microalgae Chlorella sp (FACHB-1748) under outdoor conditions. Biores Technol 138:131-135

92. Acién Fernández FC, Perez FSJA, Sevilla JMF, Grima EM (1998) Modeling of biomass productivity in tubular photobioreactors for microalgal cultures: effects of dilution rate, tube diameter, and solar irradiance. Biotechnol Bioeng 58:605-616

93. Acién Fernández F, Sevilla JMF, Pérez JAS, Grima EM, Chisti Y (2001) Airlift-driven external loop tubular photobioreactors for outdoor production of microalgae: assessment of design and performance. Chem Eng Sci 56:2721-2732

94. Andrade R, Costa JAV (2008) Outdoor and indoor cultivation of Spirulina platensis in the extreme south of Brazil. Z Naturforsch 63c:85-90

95. Benemann J, Rocheleu R (2000) Biohydrogen production. US Dept of Energy Hydrogen Program, Final summary report 1996-2000

96. Chaumont D (1993) Biotechnology of algal biomass production: a review of systems for outdoor mass culture. J Appl Phycol 5:593604

97. Bocci F, Torzillo G, Vincenzini M, Materassi R (1987) Growth physiology of Spirulina platensis in tubular photobioreactor under natural light. The 4th International Meeting on Algal
Biotechnology of the SAA Villeneuve d'Ascq, September 15-17, 1987, from Carlozzi, P. Closed photobioreactor assessments to grow, intensively, light dependent microorganisms: a twentyyear Italian outdoor investigation. The Open Biotechnology Journal 1982:1963-1972

98. Borowitzka B (1997) Microalgae for aquaculture: opportunities and constraints. J Appl Phycol 9(5):393-401

99. Little AD (1953) Pilot-plant studies in the production of Chlorella. In: Burlew JS (ed) Algal culture: from laboratory to pilot. Carnegie Institution of Washington Publications, Washington, pp. 235-272

100. Carlozzi P, Pinzani E (2005) Growth characteristics of Arthrospira platensis cultured inside a new close-coil photobioreactor incorporating a mandrel to control culture temperature. Biotechnol Bioeng 90(6):675-684

101. Carlozzi P (2003) Dilution of solar radiation through "culture" lamination in photobioreactor rows facing south north: a way to improve the efficiency of light utilization by cyanobacteria (Arthrospira platensis). Biotechnol Bioeng 81:305-315

102. Carlozzi P (2000) Hydrodynamic aspects and Arthrospira growth in two outdoor tubular undulating row photobioreactors. Appl Microbiol Biotechnol 54(1):14-22

103. Olaizola M, Duerr EO, Freeman DW (1991) Effect of $\mathrm{CO}_{2}$ enhancement in an outdoor algal production system using Tetraselmis. J Appl Phycol 3:363-366

104. Zittelli GC, Tomasello V, Pinzani E, Tedici MR (1996) Outdoor cultivation of Arthrospira platensis autumn and winter in temperate climates. J Appl Phycol 8:293-301

105. Chini Zittelli G, Lavista F, Bastianini A, Rodolfi L, Vincenzini M, Tredici MR (1999) Production of eicosapentaenoic acid by Nannochloropsis sp cultures in outdoor tubular photobioreactors. J Biotechnol 70:299-312

106. Converti A, Lodi A, Del Borghi A, Solisio C (2006) Cultivation of Spirulina platensis in a combined airlift-tubular reactor system. Biochem Engin J 32(1):13-18

107. Doucha J, Lívanský K (2006) Productivity, $\mathrm{CO}_{2} / \mathrm{O}_{2}$ exchange and hydraulics in outdoor open high density microalgal (Chlorella $\mathrm{sp}$ ) photobioreactors operated in a Middle and Southern European climate. J Appl Phycol 18:811-826

108. Sanchez S, Durand-Chastel H (1977) The utilization of Spirulina algae for industrial photosynthesis. J Phycol Suppl 13:60-71

109. García-González M, Manzano JC, Florencio FJ, Guerrero MG (2005) Production of Dunaliella salina biomass rich in 9-cisbeta-carotene and lutein in a closed tubular photobioreactor. $\mathrm{J}$ Biotechnol 115(1):81-90

110. Garcia-Malea M, Acién Fernández FG, Río ED, Fernández JM, Cerón MC, Guerrero MG, Molina-Grima E (2009) Production of astaxanthin by Haematococcus pluvialis: taking the one-step system outdoors. Biotechnol Bioeng 102(2):651-657

111. Grima E, Pérez JAS, Camacho FG, Sevilla JMF, Fernández FGA (1994) Effect of growth-rate on the eicosapentaenoic acid and docosahexaenoic acid content of Isochrysis galbana in chemostat culture. Appl Microbiol Biotechnol 41:23-27

112. Huntley MRD (2007) $\mathrm{CO}_{2}$ mitigation and renewable oil from photosynthetic microbes: a new appraisal. Mitig Adapt Strateg Glob Chang 12(4):573-608

113. Kitto MR, Regunathan C, Rodrigues A (1999) An industrial photosynthetic system for Skeletonema costatum in arid regions. J Appl Phycol 11:391-397

114. Lee Y, Low CS (1991) Effect of photobioreactor inclination on the biomass productivity of an outdoor algal culture. Biotechnol Bioeng 38(9):995-1000

115. Lee Y, Low CS (1992) Productivity of outdoor algal cultures in enclosed tubular photobioreactor. Biotechnol Bioeng 40:1119 1122

116. Mark1 $\mathrm{H}$ (1977) $\mathrm{CO}_{2}$ transport and photosynthetic productivity of a continuous culture of algae. Biotechnol Bioeng 19:1851-1862 
117. Torzillo G, Carlozzi P, Pushparaj B, Montaini E, Materassi R (1993) A two-plane tubular photobioreactor for outdoor culture of Spirulina. Biotechnol Bioeng 42(7):891-898. doi:10.1007/ s11027-11011-19294-x

118. Masojídek J, Papácěk Š, Sergejevová M, Jirka V, Červený J, Kunc J, Korečko J, Verbovikova O, Kopecký J, Štys D, Torzillo G (2003) A closed solar photobioreactor for cultivation of microalgae under supra-high irradiance: basic design and performance. J Appl Phycol 15:239-248

119. Michels M, Vaskoska M, Vermuë MH, Wijffels RH (2014) Growth of Tetraselmis suecica in a tubular photobioreactor on wastewater from a fish farm. Water Res 65:290-296

120. Mirón A, Garcia MC, Camacho FG, Grima EM, Chisti Y (2002) Growth and biochemical characterization of microalgal biomass produced in bubble column and airlift photobioreactors: studies in fed-batch culture. Enzyme and Microbial Technol 31:1015-1023

121. Mituya A, Nyunoya T, Tamiya H (1953) Pre-pilot-plant experiments on algal mass culture. In: Burlew JS (ed) Algal culture: from laboratory to pilot. Carnegie Institution of Washington Publications, Washington, pp. 273-281

122. Molina Grima E, Garcia Camacho FG, Sanchez Perez JA, Urda Cadona J, Acien Fernandez FG, Fernandez Sevilla JM (1994) Outdoor chemostat culture of Phaeodactylum tricornutum UTEX 640 in a tubular photobioreactor for the production of eicosapentaenoic acid. Biotechnol Appl Biochemistry 20(2): 279-290

123. Molina E, Fernandez J, Acien FG, Chisti Y (2001) Tubular photobioreactor design for algal cultures. J Biotechnol 92:113131

124. de Morais MG, Costa JA (2007) Biofixation of carbon dioxide by Spirulina sp and Scenedesmus obliquus cultivated in a three-stage serial tubular photobioreactor. J Biotechnol 129:439-445

125. Moreno J, Vargas MA, Rodríguez H, Rivas J, Guerrero MG (2003) Outdoor cultivation of a nitrogen-fixing marine cyanobacterium, Anabaena sp ATCC 33047. Biomolecular Engin 20(4-6): 191-197

126. Muller-Feuga A, Lemar M, Vermel E, Pradelles R, Rimbaud L, Valiorgue P (2012) Appraisal of a horizontal two-phase flow photobioreactor for industrial production of delicate microalgae species. J Appl Phycol 24:349-355

127. Olaizola M (2000) Commercial production of from Heamatococcus pluvialis using 25,000 liter outdoor photobioreactors. J Appl Phycol 12:499-506

128. Olofsson M, Lamela T, Nilsson E, Begré JP, del Pino V, Uronen P. Legrand C (2012) Seasonal variation of lipids and fatty acids of the microalgae Nannochloropsis oculata grown in outdoor largescale photobioreactors. Energies 5:1577-1592.

129. Pirt S, Lee YK, Walach MR, Pirt MW, Balyuzi HHM, Bazin MJ (1983) A tubular bioreactor for photosynthetic production of biomass from carbon dioxide: design and performance. J Chem Tech Biotechnol 33B:35-58

130. Quinn J, Yates T, Douglas N, Weyer K, Butler J, Bradley TH, Lammers PJ (2012) Nannochloropsis production metrics in a scalable outdoor photobioreactor for commercial applications. Biores Technol 117:164-171

131. Rebolloso Fuentes M, García Sánchez JL, Fernández Sevilla JM, Acién Fernéndez FG, Sánchez Pérez JA, Molina Grima E (1999) Outdoor continuous culture of Porphyridium cruentum in a tubular photobioreactor: quantitative analysis of the daily cyclic variation of culture parameters. J Biotechnol 70:271-288

132. Richmond A, Boussiba S, Vonshak A, Kopel R (1993) A new tubular reactor for mass production of microalgae outdoors. $\mathrm{J}$ Appl Phycol 5:327-332

133. Sato T, Usui S, Tsuchiya Y, Kond Y (2006) Invention of outdoor closed type photobioreactor for microalgae. Energy Conversion \& Management 47:791-799
134. Sobczuk T, Camacho FG, Rubio FC, Fernändez FGA, Grima EM (2000) Carbon dioxide uptake efficiency by outdoor microalgal cultures in tubular airlift photobioreactors. Biotechnol Bioeng 67(4):465-475

135. Torzillo G, Pushparaj B, Bocci F (1986) Production of Spirulina biomass in closed photobioreactors. Biomass 11:61-74

136. Torzillo G, Bocci F, Pushparaj B (1987) Studies on the production of Spirulina biomass through outdoor culture in tubular photobioreactor. The 4th International Conference on Biomass for Energy and Industry Orléans, May 11-15, 1987. In Carlozzi, P. Closed photobioreactor assessments to grow, intensively, light dependent microorganisms: a twenty-year Italian outdoor investigation. The Open Biotechnology Journal 1982:1963-1972

137. Torzillo G, Sacchi A, Materassi R (1991) Temperature as an important factor and night biomass loss in Spirulina platensis grown outdoors in tubular photobioreactors. Biores Technol 38:95-100

138. Tredici M, Chini Zittelli G (1991) Efficiency of sunlight utilization: tubular versus flat photobioreactors. Biotechnol Bioeng 57(2):187-197

139. Ugwu CU, Ogbonna JC, Tanaka H (2002) Improvement of mass transfer characteristics and productivities of inclined tubular photobioreactors by installation of internal static mixers. Appl Microbiol Biotechnol 58(5):600-607

140. Ugwu C, Aoyagi H (2011) Evaluation of the mass transfer capacity of a long tubular photobioreactor with static mixer and its outdoor performance with microalgal cultures. Trends in Appl Sci Res 6(10):1222-1229

141. Van Bergeijk S, Salas-Leiton E, Cañavate JP (2010) Low and variable productivity and low efficiency of mass cultures of the haptophyte Isochrysis aff. galbana (T-iso) in outdoor tubular photobioreactors. Agri Eng 43(41):14-23

142. Pulz O, Scheibenbogen K (1998) Photobioreactors - design and performance with respect to light energy input. In: Scheper T (ed) Advances in biochemical Engin/Biotechnol 59, Springer-Velag, Berlin, 123-152. dio: 10.1007/BFb0102298

143. Acién Fernández F, Hall DO, Guerrero CE, Krishna Rao K, Molina Grima E (2003) Outdoor production of Phaeodactylum tricornutum biomass in a helical reactor. J Biotechnol 103:137152

144. Borowitzka MA (1998) Tubular photobioreactors for large-scale algal culture. In: Subramanian G, Kaushik BD, Venkatamaran GS (eds) Cyanobacterial biotechnology. Oxford \& IBH Publishing Co, New Delhi, pp. 249-257

145. Borowitzka MA (1999) Commercial production of microalgae: ponds, tanks, tubes and fermenters. Biotechnol 70:313-321

146. Briassoulis D, Panagakis P, Chionidis M, Tzenos D, Lalos A, Tsinos C, Berberidis K, Jacobsen A (2010) An experimental helical-tubular photobioreactor for continuous production of Nannochloropsis sp. Biores Technol 101:768-6777

147. Camacho Rubio F, Acién Fernández FG, Sánchez Perez JA, García Camacho F, Molina Grima E (1999) Prediction of dissolved oxygen and carbon dioxide concentration profiles in tubular photobioreactors for microalgal culture. Biotechnol Bioeng 62(1):71-86

148. Chrismada T, Borowitzka MA (1994) Effect of cell density and irradiance on growth, proximate composition and eicosapentaenoic acid production of Phaeodactylum tricornutum grown in a tubular photobioreactor. J Appl Phycol 6(1):67-74

149. Hall D, Fernández FGA, Guerrero EC, Rao KK, Grima EM (2003) Outdoor helical tubular photobioreactors for microalgal production: modelling of fluid dynamics and mass transfer and assessment of biomass productivity. Biotechnol Bioeng 82(1): $62-73$

150. Lai J, Yusoff FM, Shariff M (2012) Large-scale culture of a tropical marine microalga Chaetoceros calcitrans Paulsen Takano 
1968 at different temperatures using annular photobioreactors. Pak J Biol Sci 15:635-640

151. Lee Y, Ding SY, Low CS, Chang YC, Forday WL, Chew PC (1995) Design and performance of an a-type tubular photobioreactor for mass cultivation of microalgae. J Appl Phycol 7:47-51

152. Travieso L, Hall DO, Rao KK, Benítez F, Sánchez E, Borja R (2001) A helical tubular photobioreactor producing Spirulina in a semicontinuous mode. International Biodeterioration \& Biodegradation 47(3):151-166

153. Scragg A, Illman AM, Carden A, Shales SW (2002) Growth of microalgae with increased caloric values in a tubular bioreactor. Biomass Bioenergy 23:67-73

154. Watanabe Y, de la Noüe J, Hall DO (2004) Photosynthetic performance of a helical tubular photobioreactor incorporating the cyanobacterium Spirulina platensis. Biotechnol Bioeng 47(2):261269

155. Bazaes J, Sepulveda C, Acién FG, Morales J, Gonzales L, Rivas M, Riquelme C (2012) Outdoor pilot-scale production of Botryococcus braunii in panel reactors. J Appl Phycol 24:13531360

156. Cheng-Wu Z, Zmora O, Kopel R, Richmond A (2001) An industrial-size flat plate glass reactor for mass production of Nannochloropsis sp (Eustigmatophyceae). Aquaculture 195(12):35-49

157. Cuaresma M, Janssen M, Vilchez C, Wijffels RH (2009) Productivity of Chlorella sorokiniana in a short light-path (SLP) panel photobioreactor under high irradiance. Biotechnol Bioeng 104(2):352-359

158. Degen J, Uebele A, Retze A, Schmid-Staiger A, Trösch W (2001) A novel airlift photobioreactor with baffles for improved light utilization through the flashing light effect. J Biotechnol 92:89-94

159. Dianursanti, Santoso A (2015) Increasing lipid accumulation of Chlorella vulgaris using Spirulina platensis in flat plate reactor for synthesizing biodiesel. The 3rd Indo-EBTKE ConEx 2014. Energy Procedia 65:58-66. doi:10.1016/j.egypro.2015.1001.1032

160. Feng P, Yang K, Xu Z, Wang Z, Fan L, Qin L, Zhu S, Shang C, Chai P, Yuan Z, Hu L (2014) Growth and lipid accumulation characteristics of Scenedesmus obliquus in semi-continuous cultivation outdoors for biodiesel feedstock production. Biores Technol 173:406-414

161. Grobbelaar J, Kurano N (2003) Use of photoacclimation in the design of a novel photobioreactor to achieve high yields in algal mass cultivation. J Appl Phycol 15:121-126

162. Huang J, Feng F, Wan M, Ying J, Li Y, Qu X, Pan R, Shen G, Li W (2015) Improving performance of flat-plate photobioreactors by installation of novel internal mixers optimized with computational fluid dynamics. Biores Technol 182:151-159

163. Huang J, Li Y, Wan M, Yan Y, Feng F, Qu X, Wang J, Shen G, Li W, Fan J, Wang W (2014) Novel flat-plate photobioreactors for microalgae cultivation with special mixers to promote mixing along the light gradient. Biores Technol 159:8-16

164. Hu Q, Guterman H, Richmond A (1996) A flat inclined modular photobioreactor for outdoor mass cultivation of photoautotrophs. Biotechnol Bioeng 51:51-60

165. Hu Q, Kurano N, Kawachi N, Iwasaki I (1998) Ultrahigh-celldensity culture of a marine green alga Chlorococcum littorale in a flat-plate photobioreactor. Appl Microbiol Biotechnol 49:655662

166. Hu Q, Zarmi Y, Richmond A (1998) Combined effects of light intensity, light-path and culture density on output rate of Spirulina platensis Cyanobacteria. Eur J Phycol 33(2):165-171

167. Issarapayup K, Powtongsook S, Pavasant P (2009) Flat panel airlift photobioreactors for cultivation of vegetative cells of microalga Haematococcus pluvialis. J Biotechnol 142(3):227232
168. Mansa R, Tahir A, Hua LM, Dayou J, Sipaut CS (2012) Design of a pilot scale outdoor photobioreactor for mass cultivation of local microalga. International Journal of Engineering and Physical Sciences 6:348-349

169. Moheimani N (2005) The culture of coccolithiphirid algae for carbon dioxide bioremediation. Murdoch Univeristy Australia, Dissertation

170. Ramos de Ortega A, Roux JC (1986) Production of Chlorella biomass in different types of flat bioreactors in temperate zone. Biomass 10:141-156

171. Richmond A, Cheng-Wu Z (2001) Optimization of a flat plate glass reactor for mass production of Nannochloropsis sp outdoors. J Biotechnol 85(3):259-269

172. Richmond A, Cheng-Wu Z, Zarmi Y (2003) Efficient use of strong light for high photosynthetic productivity: interrelationships between the optical path, the optimal population density and cell-growth inhibition. Biomol Engin 20(4-6):229-236

173. Rodolfi L, Zittelli G, Bassi N, Padovani G, Biondi N, Bonini G, Tredici MR (2009) Microalgae for oil: strain selection, induction of lipid synthesis and outdoor mass cultivation in a low-cost photobioreactor. Biotechnol Bioeng 102(1):100-112

174. Ruiz J, Álvarez-Díaz PD, Arbib Z, Garrido-Pérez C, Barragán J, Perales JA (2013) Performance of a flat panel reactor in the continuous culture of microalgae in urban wastewater: prediction from a batch experiment. Biores Technol 127:456-463

175. Samson R, LeDuy A (1985) Multistage continuous cultivation of blue-green alga Spirulina maxima in the flat tank photobioreactors with recycle. Canadian J Chemical Eng 63:105-112

176. Satoh A, Ichii K, Matsumoto M, Kubota C, Nemoto M, Tanaka M, Yoshino T, Matsunaga T, Tanaka T (2013) A process design and productivity evaluation for oil production by indoor mass cultivation of a marine diatom, Fistulifera sp JPCC DA0580. Biores Technol 137:132-138

177. Tredici M, Materassi R (1992) From open ponds to vertical alveolar panels: the Italian experience in the development of reactors for the mass cultivation of phototrophic microorganisms. J Appl Phycol 4:221-231

178. Tredici M, Carlozzi P, Chini Zittelli G (1991) A vertical alveolar panel (VAP) for outdoor mass cultivation of microalgae and cyanobacteria. Biores Technol 38:153-159

179. Tredici M, Zittelli GC, Biagiolini S, Materassi R (1993) Novel photobioreactor for the mass cultivation of Spirulina spp. Bull Inst Oceanogr Monaco special 12:89-96

180. Wang L-L, Tao Y, Mao X-Z (2014) A novel flat plate algal bioreactor with horizontal baffles: structural optimization and cultivation performance. Biores Technol 164:20-27

181. Zhang C, Richmond A (2003) Sustainable, high-yielding outdoor mass cultures of Chaetochoceros muelleri var subsalsum and Isochrysis galbana in vertical plate reactors. Mar Biotechnol 5(3):302-310

182. Zittelli G, Pastorelli R, Tredici MR (2000) A modular flat panel photobioreactor (MFPP) for indoor mass cultivation of Nannochloropsis sp under artificial illumination. J Appl Phycol 12(3-5):521-526

183. Zou N, Richmond A (1999) Effect of light-path length in outdoor flat plate reactors on output rate of cell mass and of EPA in Nannochloropsis sp. J Biotechnol 70:351-356

184. Zou N, Zhang C, Cohen Z, Richmond A (2000) Production of cell mass and eicosapentaenoic acid (EPA) in ultrahigh cell density cultures of Nannochloropsis sp (Eustigmatophyceae). Eur J Phycol 35:127-133

185. Doucha J, Straka F, Lívanský K (2005) Utilization of flue gas for cultivation of microalgae (Chlorella $\mathrm{sp}$ ) in an outdoor open thinlayer photobioreactor. J Appl Phycol 17:403-412 
186. Doucha J, Lívanský K (2008) Outdoor open thin-layer microalgal photobioreactor-potential productivity. J Appl Phycol 21:111117

187. Torzillo G, Giannelli L, Martínez-Roldán AJ, Verdone N, De Filippis P, Scarsella M, Bravi M (2010) Microalgae culturing in thin-layer photobioreactors. Chem Eng Trans 20:265-270

188. Morita M, Watanable Y, Okawa T, Saiki H (2001) Photosynthetic productivity of conical helical tubular photobioreactors incorporating Chlorella sp under various culture medium flow conditions. Biotechnol Bioeng 74:135-144

189. Masojídek J, Kopecký J, Giannelli L, Torzillo G (2011) Productivity correlated to photobiochemical performance of Chlorella mass cultures grown outdoors in thin-layer cascades. $\mathrm{J}$ Ind Microbiol Biotechnol 38(2):307-317

190. Borowitzka MA (2013) Energy from microalgae: a short history. In: Borowitzka MA, Moheimani, NR (eds) Algae for Biofuels and Energy, Developments in Applied Phycology, 5, Springer, pp 112

191. Becker EW (1994) Microaglae biotechnology and microbiology. Cambridge University Press Cambridge

192. Chisti Y (2007) Biodiesel from microalgae. Biotechnol Adv 25: 294-306

193. Acién Fernández F, Fernández Sevilla JM, Molina Grima E (2013) Photobioreactors for the production of microalgae. Rev Environ Sci Biotechnol 12:131-151

194. Andersen R (2005) Algal culturing techniques. Elsevier Press, Amsterdam

195. Borowitzka M, Borowitzka LJ (1988) Dunaliella. In: Borowitzka MA, Borowitzka LJ (eds) Micro-algal biotechnology. Cambridge University Press, Cambridge, pp. 27-58

196. Carlozzi P (2008) Closed photobioreactor assessments to grow, intensively, light dependent microorganisms: a twenty-year Italian outdoor investigations. The Open Biotechnology Journal 2:63-72

197. Carvalho A, Carvalho P, Meireles L, Malcata FX (2006) Microalgal reactors: a review of enclosed system designs and performances. Biotechnol Prog 22(6):1490-1506

198. Huang G, Chen F, Wie F, Zhang XW, Chen G (2010) Biodiesel production by microalgal biotechnology. Appl Energy 8:38-46

199. leB Williams PJ, Laurens LML (2010) Microalgae as biodiesel \& biomass feedstocks: review \& analysis of the biochemistry, energetics \& economics. Energy Environ Sci 3:554-590.

200. Sing S, Isdepsky A, Borowitzka MA, Moheimani NR (2013) Production of biofuels from microalgae. Mitigation and Adaptation of Strategies for Global Change 18(1):47-72. doi:10.1007/s11027-11011-19294-x

201. Belay A (2002) Mass cultivation of Spirulina outdoors. In: Vorshak A (ed) Spirulina platensis (Arthospira) physiology, cellbiology and biotechnology. Taylor and Francis Press, London, pp. 131-158

202. Klein-Marcuschamer D, Chisti Y, Benemann JR, Lewis D (2013) A matter of detail:assessing the true potential of microalgal biofuels. Biotechnol Bioeng 110(9):2317-2322

203. Bennemann J, Weissman JC, Koopman BL, Oswald WJ (1977) Energy production by microbial photosynthesis. Nature 256:19-23

204. Oswald W, Gotaas HB, Lugwig HF, Lynch V (1953) Photosynthetic oxygenation. Sewage and Industrial Wastes 25(6):692-705

205. Round F (1981) The ecology of algae. Cambridge University Press, Cambridge

206. Cupp E (1943) Marine planktonic diatoms of the west coast of North America. Scripps Bulletin University of California Press Berkeley and Los Angeles 5(1):1-237

207. Strathmann R (1967) Estimating the organic carbon content of phytoplankton from cell volume and plasma volume. Limnol Oceanogr 12(3):411-418
208. Reynolds C (1984) The ecology of freshwater phytoplankton. Cambridge University Press, Cambridge

209. Banse K (1982) Cell volumes, maximal growth rates of unicellular algae and ciliates, and the role of ciliates in the marine pelagia. Limnol Oceanogr 27:1059-1071

210. Buitenhuis E, Pangerc T, Franklin DJ, Le Quéré C, Malin G (2008) Growth rates of six coccolithophorid strains as a function of temperature. Limnol Oceanogr 53(3):1181-1185

211. Neilsen S (2006) Size-dependent growth rates in eukaryotic and prokaryotic algae exemplified by green algae and cyanobacteria: comparisons between unicells and colonial growth forms. J Plankton Res 28(5):489-498

212. Marañón E, Cermeño P, López-Sandoval DC, Rodríguez-RamosT SC, Huete-Ortega M, Blanco JM, Rodríguez J (2013) Unimodal size scaling of phytoplankton growth and the size dependence of nutrient uptake and use. Ecological Letters 16:371-379

213. Augusti S, Kalff J (1989) The influence of growth conditions on size dependence of maximal algal density and biomass. Limnol Oceanogr 34(6):1104-1108. doi:10.1007/s11027-011-9294-x

214. Rodríguez J, Mullin MM (1986) Relationship between biomass and body weight of plankton in a steady state oceanic system. Limnol Oceanogr 31(2):361-370

215. Huete-Ortega M, Cermeño P, Calvo-Díaz A, Marañón E (2012) Isometric size-scaling of metabolic rate and the size abundance distribution of phytoplankton. Proceeding of the Royal Society 279(1734):1815-1823

216. Syrett P, Morris I (1963) The inhibition of nitrate assimilation by ammonium in Chlorella. Biochimica et Biophysica Acta (BBA) Specialized Section on Enzymological Subjects 67:566-575

217. Beardall J, Raven RA (2013) Limits to phototrophic growth in dense culture: $\mathrm{CO}_{2}$ supply and light. In Borowitzka MA, Moheimani NR (eds) Development in Applied Phycology, 5, Springer, pp 91-97

218. Sathish A, Sims RC (2012) Biodiesel from mixed culture algae via a wet lipid extraction procedure. Biores Technol 118:643-647

219. Strickland J (1966) Measuring the production of marine phytoplankton. Bulletin No 122 Fisheries Research Board of Canada, Ottawa

220. Guiry M, Guiry GM (2014) AlgaeBase. http://www.algaebaseorg

221. Ahsan M, Habib B, Parvin M, Huntington TC, Hasan MR (2008) A review on culture, production and use of Spirulina as food for humans and feeds for domestic animals and fish. FAO Fisheries and Aquaculture Circular Rome FAO No. 1034, pp 1033

222. Tredici M, Chini Zittelli G, Rodolfi L (2010) Photobioreactors. In: Flickinger MC, Anderson S (eds) Encyclopedia of industrial biotechnology. John Wiley \& Sons, New York, pp. 1-15

223. Rasala B, Gimpel JA, Tran M, Hannon MJ, Miyake-Stoner SJ, Specht EA, Mayfield SP (2013) Genetic engineering to improve algal biofuels production. In Borowitzka MA, Moheimani NR (eds) Development in Applied Phycology, 5, Springer, pp 99-113

224. Guschina I, Harwood JL (2013) Algal lipids and their metabolism, Borowitzka MA, Moheimani NR (eds) Development in Applied Phycology, 5, Springer, pp 17-36

225. Fenchel T (1974) Intrinsic rate of natural increase: the relationship with body size. Oecologia 14:317-326

226. Brown J, Gillooly J, Allen AP, Savage VM, West GW (2004) Toward a metabolic theory of ecology. Ecology 85:1771-1789

227. Kolokotrones T, Savage V, Deeds EJ, Fontana W (2010) Curvature in metabolic scaling. Nature 464:753-756

228. Chen B, Liu HB (2011) Unimodal relationship between phytoplankton mass-specific-growth rate and size - a reply to the comment by Sal and López-Urrutia (2011). Limnol Oceanogr 56: 1956-1958

229. Chisholm S (1992) Population size. In: Falkowski PG, Woodhead $\mathrm{AD}$ (eds) Primary productivity and biogeochemical cycles in the sea. Plenum Press, New York, pp. 213-237 
230. Morel F, Hudson RJ, Price NM (1991) Limitations of productivity by trace meals in the sea. Limnol Oceanogr 36(8):1742-1755

231. Munk W, Riley GA (1952) Absorption of nutrients by aquatic plants. J Mar Res 11(2):215-240

232. Gavis J (1976) Munk and Riley revisited: nutrients diffusion transport and rates of phytoplankton growth. J Mar Res 34(2):161-240

233. Beinfang P, Harrison PJ (1984) Covariaton of sinking rate and cell quota among nutrient replete marine phytoplankton. Marine Ecological Progress Series 14:297-300

234. Granata T (1991) Diel periodicity in growth and sinking rates of the centric diatom Coscinodiscus concinnus. Limnol Oceanogr 36(1):132-139

235. Thomas W, Gibson CH (1990) Effects of small scale turbulence on microalgae. Limnol Oceanogr 2:71-77

236. Sobczuk T, García Camacho F, Molina Grima E, Chisti Y (2006) Effects of agitation on the microalgae Phaeodactylum tricornutum and Porphyridium cruentum. Bioprocess Biosystems Eng 28: 243-250

237. Whitmire A, Pegau WS, Karp-Boss L, Boss E, Cowles TJ (2010) Spectral backscattering properties of marine phytoplankton cultures. Opt Express 18(14):15073-15093

238. Kirk J (1992) The nature and measurement of the light environment in the ocean. In: Falkowski PG, Woodhead AD (eds) Primary productivity and biogeochemical cycles in the sea. Plenum Press, New York, pp. 9-29

239. Vaillancourt R, Brown CW, Guillard RRL, Balch WM (2004) Light backscattering properties of marine phytoplankton: relationships to cell size, chemical composition and taxonomy. J Plankton Res 26(2):191-212

240. Fujiki T, Taguchi S (2002) Variability in chlorophyll a specific absorption coefficient in marine phytoplankton as a function of cell size and irradiance. J Plankton Res 24(9):859-874

241. Gallagher B (2011) The economics of producing biodiesel from algae. Renew Energy 36(1):158-162

242. Singh A, Singh Nigam P, Murphy JD (2010) Renewable fuels from algae: an answer to debatable land based fuels. Bioresour Technol 102(1):10-16

243. Lundquist T, Woertz I, Quinnm N, Benemann JR (2010) A realistic technology and engineering assessment of algal biofuel production. Energy Biosciences Institute Report October 2010: Digital Commons @ Cal Poly

244. Griffiths M, Dicks RG, Richardson C, Harrison STL (2011) Advances and challanges of microalgae as a sources of oil for biofuels. Chapter 9. In Stoytcheva M Montero G (eds) Biodiesel Feedstocks and Processing Technologies http://www.intechopen. com/download/pdf/pdfs_id/22999

245. Benemann J (2009) Microalgae biofuels: a brief introduction. Benemann Associates, http://advancedbiofuelsusa.info/wp-content/uploads/2009/03/microalgae-biofuels-an-introduction-july23-2009-benemann.pdf

246. Fogg GE, Calvario-Martinez O (1989) Effects of bottle size in determinations of primary productivity by phytoplankton. Hydrobiologia 173(2):89-94

247. Molina Grima E, Acién Fernández FG, García Camacho F, Chisti Y (1999) Photobioreactors: light regime, mass transfer, and scaleup. J Biotechnol 70:231-247

248. Chaumont D, Thepenier C, Gudin C (1988) Scaling up a tubular photoreactor for continuous culture of Porphyridium cruentum - from laboratory to pilot plant. In: Morillon J, Verdus MC, Karamonos W, Morvan H, Christiae D (eds) Stadler T. Algal Biotechnology Elsevier Applied Science, London, pp. 199-208

249. Lee C, Palsson BØ (1995) Continuous medium perfusion leads to long-term cell viability and oxygen production in high-density photobioreactors. Biotechnol Letters 17:1149-1154
250. Olaizola M (2003) Commercial development of microalgal biotechnology: from the test tube to the marketplace. Biomolecular Eng 20:459-466

251. Posten C (2009) Design principles of photo-bioreactors for cultivation of microalgae. Engineering in Life Sciences 9(3):165-177

252. Eriksen N (2008) The technology of microalgal culturing. Biotechnol Lett 30:1525-1536

253. Brennan L, Owende P (2010) Biofuels from microalgae-a review of technologies for production, processing, and extractions of biofuels and co-products. Renew Sust Energ Rev 14(2):557577

254. Posten C (2012) Design and performance parameters of photobioreactors. Technikfolgenabschätzung - Theorie und Praxis 21:1-45 www.tatup-journal.de/downloads/2012/tatup121_post12a. pdf

255. Carvalho A, Silva SO, Baptista JM, Malcata FX (2011) Light requirements in microalgal photobioreactors: an overview of aspects. Appl Microbiol Biotechnol 89:1275-1288

256. Grobbelaar J (2012) Microalgae mass culture: the constraints of scaling-up. J Appl Phycol 24:315-318

257. Richmond A (2004) Principles for attaining maximal microalgal productivity in photobioreactors: an overview. Hydrobiologia 512:33-37

258. Formighieri C, Franck F, Bassi R (2012) Regulation of the pigment optical density of an algal cell: filling the gap between photosynthetic productivity in the laboratory and in mass culture. $\mathrm{J}$ Biotechnol 106(1):115-123

259. Uduman N, Qi Y, Danquah MK, Forde GM, Hoadley A (2010) Dewatering of microalgal cultures: a major bottleneck to algaebased fuels. Journal of Sustainable and Renewable Energy 2. doi:10.1063/1.3294480.

260. Borowitzka M, Moheimani NR (2011) Sustainable biofuels from algae. Mitig Adapt Strateg Global Change 18(1):13-25

261. Mata T, Martins AA, Caetano NS (2010) Microalgae for biodiesel production and other applications - a review. Renew Sust Energ Rev 14:217-232

262. Kunjapur A, Eldridge BR (2010) Photobioreactor design for commercial biofuel production from microalgae. Ind Eng Chem Res 49:3516-3526

263. Singh R, Sharma S (2012) Development of suitable photobioreactor for algae production - a review. Renew Sust Energ Rev 16:2347-2353

264. Smith V, Sturm BSM, deNoyelles FJM, Billing SA (2010) The ecology of algal biodiesel production. Trends in Ecology and Evolution 25(5):301-308

265. Wang B, Lan CQ, Horsman M (2012) Closed photobioreactors for production of microalgal biomasses. Biotechnol Adv 30:904-912

266. Tredici M, Bassi N, Prussi M, Biondi N, Rodolfi L, Zittelli GC (2015) Energy balance of algal biomass production in a 1-ha "Green Wall Panel" plant: how to produce algal biomass in a closed reactor achieving a high net energy ratio. Appl Energy 154:1103-1111

267. Sánchez Mirón A, Carmen Cerón García M, Contreras Gómeza A, García Camachoa F, Molina Grima E, Chisti Y (2003) Shear tolerance and biochemical characterization of Phaeodactylum tricornutum in quasi steady-state continuous culture in outdoor photobioreactors. Biochemical Eng J 16:287-297

268. Leupold M, Hindersin S, Gust G, Kerner M, Hanelt D (2013) Influence of mixing and shear stress on Chlorella vulgaris, Scenedesmus obliquus, and Chlamydomonas reinhardtii. J Appl Phycol 25:485-495

269. Gervais F, Opitz D, Behrendt H (1997) Influence of small-scale turbulence and large-scale mixing on phytoplankton primary production. Hydrobiologia 342(343):95-105 